\title{
MODERN INDONESIAN LITERATURE IN TRANSLATION II
}

\author{
(Compiled by Dede Oetomo)
}

This is the second part of a two-part bibliography of English translations of modern Indonesian poems, plays, short stories, and novels. The translations are divided into four sections: poetry ${ }^{1}$ ( $\mathrm{pp}$. 129-55); short stories ( $\mathrm{pp}$. 156-61); novels, and drama (pp. 161-62). The bibliography starts with a listing of some of the major collections and other sources where the translations of individual works can be found, giving the abbreviations used in the bibliography to refer to these sources. (The major likely sources of translations which have not been consulted in compiling this bibliography are recent dissertations; the only dissertations referred to are two from the 1960s.)

Within each division, the Indonesian authors are listed alphabetically, and their works are also arranged alphabetically by Indonesian title. On the few occasions when the original Indonesian work appeared under an English title, this title is alphabetized along with the Indonesian. If the Indonesian work was untitled, or if we are unaware of that title, it appears at the end of the author's listing, and is alphabetized in accordance with the title of the English translation. In such instances, its original title is indicated by "_.." When a number of English translations of a single Indonesian work have been published, they are listed alphabetically by translator; and if a single translator has published several translations of the same poem or short story, his translations are listed chronologically according to their publication date.

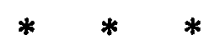

\section{SOURCES}

\section{Ali, Flaming Earth}

Aveling, "Poetry \& the Indonesian Revolution"

Aveling, "Contemporary"
Ali, Ahmed, ed., tr. The Flaming Earth: Poems from Indonesia. Karachi: Friends of the Indonesian People Society, 1949.

Aveling, Harry G. "Poetry and the Indonesian Revolution: The Verse of Rivai Apin and Taufiq Ismail," Westerly, 1 (May 1970), pp. 43-46.

Aveling, Harry G. "Contemporary Indonesian Poetry," in 20th Century, 25, 2 (Summer 1970), pp. 101-9.

1. This listing does not include translations of Chairil Anwar's poetry, which appeared in Part I of the bibliography (Indonesia, 29 [April 1980], pp. 91-111). 
Aveling, "Impressions"

Aveling, Indonesian Poet

Aveling, "Melody"

Aveling, Rendra

Aveling, Translations

Aveling, Goenawan

Aveling, Thematic History

Aveling, CIP

Aveling, Gestapu

Aveling, Ariuna

Aveling, SurabayaArmageddon

Beier, Only Dust

Bintang Suradi, We All Are

Bintang Suradi, CPIP

Bintang Suradi, Indonesia Sings
Aveling, Harry. "Impressions of Literary Life in Indonesia," in Solidarity, 6, 3 (March 1971), pp. 66-72.

Aveling, Harry, tr. Indonesian Poet in New York: Poems 1964-1968 [by] W. S. Rendra [trans. of Blues untuk Bonnie]. Melbourne: Dept. of Indonesian \& Malay, Monash University, 1971.

Aveling, Harry G. "Melody and Meditation: An Introduction to the Work of Two Contemporary Indonesian Poets (W. S. Rendra and Sapardi Djoko Damono)," Poetry Australia, 41 (1971), pp. 53-64.

Aveling, H. G. W. S. Rendra. Poetry International, Rotterdamse Kunststichting, 1971, unpaged, mimeo. (Translators of the poems are not indicated, but seem to be either Aveling or Raffel.)

Aveling, Harry. Translations of Contemporary Indonesian Poetry. New York: Asia Society, 1972.

Aveling, Harry. Coenawan Mohammad. Poetry International, Rotterdamse Kunststichting, 1973, mimeo.

Aveling, Harry. A Thematic History of Indonesian Poetry: 1920 to 1974. Special Report No. 9. Center for Southeast Asian Studies, Northern Illinois University, 1974.

Aveling, Harry, ed., tr. Contemporary Indonesian Poetry. St . Lucia, Queensland: University of Queensland Press, 1975.

Aveling, Harry, ed., tr. Gestapu: Indonesian Short Stories on the Abortive Communist Coup of 30th September 1965. Honolulu: Southeast Asian Studies Program, University of Hawaii, 1975.

Aveling, Harry, ed., tr. Arjuna in Meditation: Three Young Indonesian Poets: Selected verse of Abdul Hadi W. M. , Darmanto Jt., and Sutardji Calzoum Bachri. Calcutta: Writers' Workshop, 1976.

Aveling, Harry, ed., tr. From Surabaya to Armageddon: Indonesian Short Stories. Singapore: Heinemann Educational Books (Asia), 1976.

Only Dust: Three Modern Indonesian Poets. English version by Ulli Beier. Port Moresby, New Guinea: Papua Pocket Poets, 1969.

Bintang Suradi, tr. We All Are Lumumba. Jakarta: League of People's Culture, 1961 [?].

Bintang Suradi, ed., tr. Contemporary Progressive Indonesian Poetry. Jakarta: Lekra, 1962 [?].

Bintang Suradi, tr. Indonesia Sings of Afro-Asia. Jakarta: League of People's Culture, 1962. 


\author{
"Chapbook" \\ Diat, Four Poems \\ Dickinson, "Selected Social \\ \& Ethical Values"
}

Echols, IWT

Foulcher, "PMSP"

Hendon, Six Indonesian Short Stories

Hilgers-Hesse, "Some Thoughts"

José, A sian PEN

Moerdowo, Sociological Aspects

Nababan, "Linguistic Analysis"

POI

Poetry Reading

Pramoedya, Heap of Ashes

Raffel, AMIP

Raffel, "Beginnings"

Raffel, Development
"A Chapbook of Contemporary Asian Poetry," The Beloit Poetry Journal, 13, 2 (1962-63).

Diat, Akhu. Some Contemporary Indonesian Playwrights and Four Poems: A Presentation. Iowa City: International Writing Program, University of lowa, 1975, unpaged.

Dickinson, Donna M. "Selected Social and Ethical Values in Indonesian Literature, 1900-1960." $\mathrm{Ph} . \mathrm{D}$. dissertation, University of California at Berkeley, 1963.

Echols, John M. Indonesian Writing in Translation. Ithaca: Cornell Modern Indonesia Project, 1956.

Foulcher, Keith. "Perceptions of Modernity and the Sense of the Past: Indonesian Poetry in the 1920s," in Indonesia, 23 (April 1977), pp. 39-58.

Hendon, Rufus S., tr. Six Indonesian Short Stories. Yale University Southeast Asia Studies, Translation series No. 7. New Haven: Yale University, 1968.

Hilgers-Hesse, Irene. "Some Thoughts on Indonesian Authors of the 1970s," Indonesia Circle, 20 (Nov. 1979), pp. 11-16.

Sionil, José F. Asian PEN Anthology. Manila: Solidaridad, 1966 (New York: Taplinger Publishing, 1967).

Moerdowo, Raden. Sociological Aspects of Modern Indonesian Literature. London: Cultural Department, Embassy of the Republic of Indonesia, 195?.

Nababan, Sri Utari Subjakto. "A Linguistic Analysis of the Poetry of Amir Hamzah and Chairil Anwar." Ph.D. dissertation, Cornell University, 1966.

Perspective of Indonesia, supplement to Atlantic Monthly, June 1956.

Clayton Arts Council, Arts Festival 1971. Poetry Reading. Oakleigh, 1971.

Pramoedya Ananta Toer. A Heap of Ashes. Ed. \& tr. by Harry Aveling. St. Lucia, Queensland: University of Queensland Press, 1975.

Raffel, Burton, ed. An Anthology of Modern Indonesion Poetry. Berkeley and Los Angeles: University of California Press, 1964.

Raffel, Burton. "The Beginnings of Modern Indonesian Poetry," Asia, no. 2 (Autumn 1964), pp. 67-79.

Raffel, Burton. The Development of Modern Indonesian Poetry. Albany: SUNY Press, 1967. 
Raffel, Forked Tongue

Rendra, Ballads \& Blues

RIMA

Salleh, Tradition \& Change

Shimer, Mentor Book

$S I L$

Surjotjondoro-Leake, "Kayon"

Teeuw, MIL

20th Century

Usman, "Introduction"

van der Kroef, "Modern Trends"

Wigmore, Span
Raffel, Burton. The Forked Tongue: A Study of the Translation Process. The Hague: Mouton, 1971.

Rendra, W. S. Ballads and Blues: Poems. Translated by Burton Raffel, Harry Aveling and Derwent May, with a preface by A. H. Johns. Kuala Lumpur: Oxford University Press, 1974.

Review of Indonesian and Malayan Affairs.

Salleh, Muhammad Haji. Tradition and Change in Contemporary Malay-Indonesian Poetry. Kuala Lumpur: Universiti Kebangsaan Malaysia, 1977.

Shimer, Dorothy Blair, ed. The Mentor Book of Modern Asian Literature, from the Khyber Pass to Fuji. New York: The New American Library, 1969.

Survey of Indonesian Literature. New York: Indonesian Information Office, 1953.

Surjotjondoro-Leake, Diyan Parahitani. "Kayon: Poems by Subagio Sastrowardojo," Indonesia Circle, 21 (March 1980), pp. 32-39.

Teeuw, A. Modern Indonesian Literature. The Hague: Nijhoff, 1967.

20th Century: An Australian Quarterly Review (Kew, Victoria, Australia).

Usman Sastroamidjojo, $R$. "An Introduction to Indonesian Poetry," in Poetry: The Australian International Quarterly of Verse, 25 (Dec. 10, 1947), pp. 30-37. [Most poems translated by Sularko.]

van der Kroef, Justus M. "Modern Trends in Indonesian Literature," Journal of East Asiatic Studies, 3 (Jan. 1954), pp. 131-52.

Wigmore, Lionel, ed. Span: An Adventure in Asian and Australian Writing. Melbourne: Cheshire, 1958. 


\section{POETRY}

ABDUL Hadi W. M. (Widji Muthari)

Angin: mendesir lagi "The wind," tr. Aveling, in Ariuna, p. 25.

Baitl Makdis, pada Malam Israk "Commemoration of Muhammad's flight to Jerusalem," tr. Aveling, in ibid., p. 37.

Bangku bangku taman "Park benches," tr. Aveling, in ibid., p. 27.

Elegi I "Elegy I," tr. Aveling, in ibid., p. 49.

Elegi II "Elegy II," tr. Aveling, in ibid., p. 50.

Elegi III

"Elegy III," tr. Harry Aveling, in Modern Poetry in Translation, 19/20 $(1974)$, p. 43.

"Elegy III," tr. Aveling, in Arjuna, pp. 51-52.

Engkau menunggu kemarau "Waiting for the dry season," tr. Aveling, in ibid., p. 23.

Exodus "Exodus," tr. Aveling, in ibid., p. 32 .

Gnoti seauton "Gnoti seauton," tr. Aveling, in ibid., p. 29.

Hotel "Hotel," tr. Aveling, in ibid., p. 31 .

La condition humaine "La condition humaine," tr. S. Sutro, in Westerly, 24, 3 (Sept. 1979), p. 65.

Lagu dalam hudjan "The song of the rain," tr. Aveling, in Ariuna, p. 30.

Malam laut "Sea night," tr. Aveling, in ibid., p. 24.

Malam teluk "Night over the bay," tr. Aveling, in ibid., p. 48.

Meditasi "Meditation," tr. Aveling, in ibid., pp. 43-44.

Memandang "Watching," tr. Aveling, in ibid., pp. 34-35.

Mesdjid "Mosque," tr. Aveling, in ibid., pp. 38-39.

Mikraj "The ascension of Muhammad," tr. Aveling, in ibid., p. 36.

Percakapan "Conversation," tr. Aveling, in ibid., p. 47.

Prelude

"Prelude," tr. Aveling, in ibid., p. 19.

"Prelude," tr. Salleh, in Tradition \& Change, pp. 165-66 (BT).

Ruh "Soul," tr. Aveling, in Ariuna, p. 28.

Sajak putih "White poems," tr. Aveling, in ibid., p. 42.

Sebuah suara "A voice," tr. Aveling, in ibid., p. 40.

Sendiri "Alone," tr. Aveling, in ibid., p. 33.

Seperti burung-burung "Like birds," tr. Aveling, in ibid., p. 41.

Surabaya I "Surabaya," tr. Aveling, in ibid., p. 58.

. "A landscape for Angela Davis," tr. Aveling, in ibid., p. 45.

_. "A poem for darkness," tr. Aveling, in ibid., p. 26.

. "A scene," tr. Aveling, in ibid., p. 54.

"A simple song VIII," tr. Aveling, in ibid., p. 46.

- "A song of fog," tr. Aveling, in ibid., p. 56 .

"En soi," tr. Aveling, in ibid., p. 22.

"Journey," tr. Aveling, in ibid., p. 53.

- "Meditation," tr. Harry Aveling, in Murdoch News, 3, 1 (Autumn 1975[?]), p. 8.

"Meditation," tr. Aveling, in Arjuna, p. 57.

"Meditation," tr. Aveling, in Westerly, 4 (Dec. 1976), p. 45.

"Moonlight," tr. Aveling, in Ariuna, p. 55.

"Nest," tr. Aveling, in ibid., p. 21.

"Obscure poem," tr. Aveling, in ibid., p. 20.

"Song for Abdul Hadi," tr. by the poet with Bert Blume, in Modern Poetry in Translation, 19/20 (1974), p. 43 . 
AGAM Wispi

Buchenwald "Buchenwald," tr. Raffel, in Development, p. 149.

Demokrasi

"Democracy," tr. Bintang Suradi, in CPIP, p. 82.

"Democracy," tr. Bintang Suradi, in Raffel, Development, p. 150.

Gadis luar kota "Outside the city: a girl," tr. Raffel, in ibid., p. 150.

Matinja seorang petani "The death of a peasant," tr. Bintang Suradi, in CPIP, pp. 79-81.

Repolusi

"Revolution," tr. Bintang Suradi, in ibid., p. 78.

"Revolution," tr. Raffel, in Development, p. 149 (BT).

AIDIT, D. N. (Dipa Nusantara)

. "Coming of age," tr. Bintang Suradi, in CPIP, p. 17.

- "Granite wall" tr. Bintang Suradi, in ibid., p. 19.

- "The dead will live eternally," tr. Bintang Suradi, in Indonesia Sings, p. 1.

- "The only road," tr. Bintang Suradi, in CPIP, p. 18.

AIDIT, Sobron

Kenangan sedih petani Tjiandjur "Sad memories of a Tjiandjur peasant," tr. Bintang Suradi, in ibid., pp. 20-21.

Setia kawan "Loyal friends," tr. Raffel, in Development, p. 148.

- "Life," tr. Bintang Suradi, in CPIP, p. 22.

. "The society of my class," tr. Bintang Suradi, in ibid., pp. 23-24.

AJIP Rosidi

Antara kita

"Between us," tr. Aveling, in Translations, p. 15.

"Between us," tr. Aveling, in CIP, pp. 78-79 (BT).

Bayangan

"The shadow," tr. Taufiq Ismail, in Solidarity, 3, 9 (Sept. 1968), p. 60.

"Image," tr. Aveling, in Translations, p. 15.

"Image," tr. Aveling, in CIP, pp. 80-81 (BT).

Di sini segalanya tak mengenal waktu

"Here time's dimensions are unknown," tr. Aveling, in Translations, p. 19.

"Here time's dimensions are unknown," tr. Aveling, in CIP, pp. 92-93 (BT).

Doa "Prayer," tr. Aveling, in Translations, p. 20.

"Prayer," tr. Aveling, in CIP, pp. 94-95.

Hanya dalam puisi

"Only in poetry," tr. Aveling, in Translations, pp. 17-18.

"Only in poetry," tr. Aveling, in CIP, pp. 84-87 (BT).

Kalau kau datang "When you come," tr. Burton Raffel \& Nurdin Salam, in Raffel, Development, p. 167.

Ketetapan "Resolution," tr. Raffel, in ibid., pp. 168-69.

Moksha "Release," tr. Raffel, in ibid., p. 164.

Panmunjon [sic]

"Panmunjon [sic]," tr. Aveling, in Translations, p. 19.

"Panmunjon [sic]," tr. Aveling, in CIP, pp. 90-91 (BT).

Pengantar "Introduction," tr. Raffel, in Development, p. 166.

Perahu meluntjur air memantjur "The prau slides through choppy water" [originally untitled], tr. Raffel, in ibid., p. 165 (BT).

Potret gadis "Portrait of a girl," tr. Salleh, in Tradition \& Change, p. 122 (BT).

Rindu "Longing," tr. Burton Raffel \& Nurdin Salam, in Raffel, Development, pp. 166-67.

Sindanglaut "Sindanglaut," tr. Saini K. M., in Solidarity, 3, 9 (Sept. 1968), pp. 60-61.

Surat tjinta Endaj Rasidin "Endai Rasidin's love letter," tr. Raffel, in Development, pp. 167-68. 
AJIP Rosidi (continued)

Terkenang topeng Cirebon

"Memory of a masked dance from Tjirebon," tr. Aveling, in Translations, p. 18.

"Memory of a masked dance from Tjirebon," tr. Harry Aveling, in Tenggara, 6 (1973), pp. 40-41 (BT).

"Memory of a masked dance from Cirebon," tr. Aveling, in CIP, pp . 88-89.

Tjatatan ${ }^{2}$ "Notes," tr. Teeuw, in MIL, pp. 237, 271 (BT).

Tjikini Raja "Tjikini Raja," tr. Teeuw, in ibid., pp. 238, 271 (BT).

Tretes malam hari

"Tretes at night," tr. Aveling, in Translations, p. 16.

"Tretes at night," tr. Aveling, in CIP, pp. 82-83 (BT).

AKBAR DJOEHANA, Mohammad see DJOEHANA, Mohammad Akbar

AKHU Diat see DIAT, Akhu

ALI Hasjmi seeHASJMI, A.

ALI S. Nazola

- "Wet monsoon," tr. M. A. Jaspan, in Indonesia, special issue of Westerly, Oct. 1966, p. 25.

ALISJAHBANA, St. Takdir see TAKDIR Alisjahbana, St.

AMIR Hamzah

Astana Réla "A palace prepared for us," tr. Dickinson, in "Selected Social \& Ethical Values," pp. 110-11.

Berdiri aku "There I stand," tr. Teeuw, in MIL, pp. 95, 264 (BT).

Buah rindu "Longing," tr. Sularko (?), in Usman, "Introduction," p. 32.

Didalam kelam "In the darkness," tr. Burton Raffel \& Nurdin Salam, in Raffel, "Beginnings," p. 78.

Doa "Prayer," tr. Burton Raffel \& Nurdin Salam, in Echols, IWT, p. 32.

"Prayer," tr. Raffel \& Salam, in POI, p. 158.

"Prayer," tr. Raffel \& Salam, in Raffel, AMIP, p. 30.

"Prayer," tr. Muhammad Haji Salleh, in Tenggara, 8 (1976), pp. 18-19 (BT).

Hang Tuah

"Hang Tuah," tr. Nababan, in "Linguistic Analysis," pp. 96-100 (BT).

"Hang Tuah," tr. Teeuw, in MIL, pp. 88, 262-63 (BT).

Hanja satu

"Only one," tr. Nababan, in "Linguistic Analysis," pp. 116-17 (BT).

"One alone," tr. Raffel, in A. H. Johns, "An Anthology of Modern Indonesian Poetry," Hemisphere, 10, 2 (Feb. 1966), p. 8 (BT).

"There is only one," tr. partly by Teeuw, partly by Raffel, in Teeuw, MIL, pp. 91, 263 (BT).

Hanjut aku

"Flotsam, I," tr. Dickinson, in "Selected Social \& Ethical Values," pp. 8-10 (BT).

"Carry me away," tr. Margaret Johns \& Robin Matheson, in Horizontal, 1 (1965), pp. 18-19 (BT).

"I am washed away," tr. Nababan, in "Linguistic Analysis," p. 130 (BT).

"I'm drifting," tr. Raffel \& Salam, in Raffel, Development, p. 69.

Harum rambutmu "The fragrance of your hair," tr. Nababan, in "Linguistic Analysis," pp. 77-78 (BT).

Kerdja semata . . . "Merely work ..." [originally untitled], tr. Nababan, in ibid., p. 132 (BT).

Kulihat tanah... "I see land ...." tr. Nababan, in ibid., pp. 135-36 (BT).

Kurnia "Grace," tr. Dickinson, in "Selected Social \& Ethical Values," p. 123.

Memudji dikau

"Praising you," tr. Dickinson, in ibid., pp. 117-18. 
AMIR Hamzah (continued)

Memudji dikau (continued)

"In praise of you," tr. Burton Raffel \& Nurdin Salam, in Poetry Northwest, 4, 3/4 (Autumn 1963/Winter 1964), pp. 56-57 (BT).

"In praise of you," tr. Raffel \& Salam, in Raffel, AMIP, p. 23.

"In praise of you," tr. Raffel \& Salam, in José, Asian PEN, p. 164.

Mengawan "Climbing to the clouds," tr. Dickinson, in "Selected Social \& Ethical Values," pp. 107-8.

Naik ${ }^{2}$ "Higher, higher," tr. Teeuw, in MIL, pp. 96, 264 (BT).

Padamu djua

"To you alone," tr. Margaret Johns \& Robin Matheson, in Horizontal, 1 (1965), pp. 20-21.

"To thee only," tr. Nababan, in "Linguistic Analysis," pp. 108-9 (BT).

"To you alone," tr. Teeuw, partially based on Raffel's tr., in M/L, pp. 100, 265-66 (BT).

Permainanmu "Thy plaything," tr. Nababan, in "Linguistic Analysis," pp. 123-24 (BT).

Sebab dikau

"Because of you," tr. Ali, in Flaming Earth, p. 33.

"Because of you," tr. Ali, in Wigmore, Span, p. 337.

"Because of you," tr. Sutan Takdir Alisjahbana, Sabina Thornton, \& Burton Raffel, in Raffel, Development, pp. 73-74.

"Because of you," tr. Alisjahbana, Thornton, \& Raffel, in Shimer, Mentor Book, pp. 66-67.

"Because of you," tr. Teeuw, exc. last two stanzas by A. H. Johns, in MIL, pp. $99,265(\mathrm{BT})$.

Senjum hatiku, senjum "Smile, my heart, smile," tr. Burton Raffel \& Nurdin Salam, in Raffel, Development, pp. 71-72.

Sunji itu duka [originally untitled] "To be lonely is sorrow," tr. Raffel, in ibid., p. 70 (BT).

Taman dunia

"Garden of the world," tr. Dickinson, in "Selected Social \& Ethical Values," pp. 123-24.

"Garden of the world," tr. Burton Raffel \& Nurdin Salam, in Raffel, Development, pp. 77-78.

Tingallah "Farewell," tr. Nababan, in "Linguistic Analysis," pp. 86-87 (BT).

Tjempaka "Tjempaka," tr. Nababan, in ibid., pp. 68-69 (BT).

Tuhanku apatah kekal? "My lord, what is lasting?" tr. Muhammad Haji Salleh, in Tenggara, 8(1976); pp. 16-17 (BT).

Turun kembali

"I step down," tr. Burton Raffel \& Nurdin Salam, in Raffel, "Beginnings," p. 77.

"I step down," tr. Raffel \& Salam, in Raffel, Development, pp. 66-67.

"Down to earth again," tr. Teeuw, in MIL, pp. 101-2, 266 (BT).

ANANT AGUNA, Sabarsantoso

Gerilja tani "Peasant guerrilla," tr. Raffel, in Development, pp. 146-47.

Jamila

"Jamila," tr. Bintang Suradi, in CPIP, p. 30.

"Jamila," tr. Bintang Suradi, in Indonesia Sings, pp. 2-3.

Lumumba "Lumumba," tr. Bintang Suradi, in We All Are, pp. 5-6.

Surat dari gunung "Letter from the mountains," tr. Raffel, in Development, pp. $145-46$.

. "The downtrodden shoulder freedom," tr. Bintang Suradi, in CPIP, p. 29.

. "To people's Bandung," tr. Bintang Suradi, in ibid., p. 31. 


\section{ANONYMOUS}

. "Freedom," tr. Imam Sutarjo, in "Literary Trends--Indonesia," Unilit (Secunderabad), 6, 3 (1966), pp. 32-33.

. "Sourabaya," tr. Sularko (?), in Usman, "Introduction," pp. 34-35.

APIN, Rivai see RIVAI Apin

ARMIJN Pané see PANÉ, Armijn

ARSJAD, M. A.

. "Native village," tr. Bintang Suradi, in CPIP, p. 32.

ASHAR, M. S.

. "Freedom and prison," tr. Bintang Suradi, in ibid., p. 33.

- "To Uncle Ho Chi Minh," tr. Bintang Suradi, in ibid., p. 34 .

"To Uncle Ho Chi Minh," tr. Bintang Suradi, in Indonesia Sings, pp. 5-6.

ASIEN [Muhamed Djunasien]

- "Housing," tr. Robin Andison, in Indonesia, special issue of Westerly (Oct. 1966), p. 19.

ASMARA Hadi

Sadjak ketjil "A little poem," tr. Teeuw, in MIL, pp. 49, 262 (BT).

ASRUL Sani

Elang laut

"The sea hawk," tr. Ali, in Flaming Earth, pp. 27-28.

"The sea hawk," tr. Y. F. Liaw, in Eastern Horizon, 1, 3 (Sept. 1960), p. 41.

Kenanglah bapa, kenanglah bapa

"Remember father, remember father," tr. Jean Kennedy, in Raffel, Development, pp. 122-23.

"Remember father, remember father," tr. Kennedy, in Shimer, Mentor Book, pp. 69-70.

Malam lampau "The past night," tr. Ali, in Flaming Earth, p. 26.

Pengungsi

"Prayer," tr. van der Kroef, in "Modern Trends," pp. 143-44.

"Refugee" [originally untitled], tr. James S. Holmes, in Raffel, Development, p. 124 .

Surat dari Ibu

"Mother's message," tr. Y. F. Liaw, in Eastern Horizon, 1, 3 (Sept. 1960), p. 40 .

"Mother's message," tr. Liaw, in M. S. Hutagalung, Tanggapan dunia Asrul Sani (Jakarta: Gunung Agung, 1967), p. 144.

- "Deception," tr. Rowena Vining \& Ahmed Ali, in Ali, Flaming Earth, p. 29.

BACHRI, Sutardji Calzoum see SUTARDJI Calzoum Bachri

BACHTIAR, Toto Sudarto see TOTO Sudarto Bachtiar

BANDAHARO, Hr. see HARAHAP, Bandaharo

BASUKI Gunawan

Ai Maria "Ai Maria," tr. Beier, in Only Dust, p. 8.

Buat W.F.v.d. "Fog," tr. Beier, in ibid., p. 11.

Kerèta api "Fiery cart," tr. Beier, in ibid., p. 4.

Kuisi bumi dengan laguku "I fill the earth," tr. Beier, in ibid., p. 7.

Malam "Night," tr. Beier, in ibid., p. 6.

Pedjuang "The warrior," tr. Beier, in ibid., p. 5.

Potrèt kawan "Portrait of a friend," tr. Beier, in ibid., p. 12. 
BASUKI Gunawan (continued)

Sudah waktu kini "The time has come," tr. Beier, in ibid., p. 9.

Tahu sudah aku "Only dust," tr. Beier, in ibid., p. 10.

BEDJO, Kr.

- "Greetings from a friend," tr. Bintang Suradi, in Indonesia Sings, p. 9.

BUR Rasuanto

Sebuah petisi kepada Jang Mulia Menteri "A petition to our lord the minister," tr. Harry Aveling, in Roger M. Smith, ed., Southeast Asia: Documents of Political Development and Change (Ithaca: Cornell University Press, 1974), pp. 210-11.

Tirani "Tyranny," tr. Harry Aveling, in ibid., p. 209.

DARMANTO Jt.

Aku menatapmu "As I watch," tr. Aveling, in Ariuna, pp. 67-68.

Apa yang sesungguhnya harus kukatakan "What can I say?" tr. Aveling, in ibid., pp. 69-71.

Apakah Kristus pernah?

"Did Christ ever?" tr. Harry Aveling, in Solidarity, 7, 5 (May 1972), p. 57.

"Did Christ ever?" tr. Aveling, in Ariuna, pp. 74-76.

Besok dan aku 27 "Tomorrow I am 27," tr. Aveling, in ibid., pp. 87-89.

Dari kaca jendela kamarku suatu senja "Twilight on the window of my room," $t r$. Aveling, in ibid., pp. 90-91.

Ini terjadi ketika matahari menggapai sia-sia "One day the sun reached futilely out, "tr. Aveling, in ibid., pp. 77-78.

Interferensi lonceng-lonceng mekanik "The jangle of mechanical bells," tr. Aveling, in Thematic History, p. 70 .

Menghadapmu pagi ini "At dawn," tr. Aveling, in Arjuna, p. 73.

Pa sia pa "Who are you," tr. Aveling, in ibid., pp. 81-83.

Siapakah kau, aku?

"Who are you/me?" tr. Aveling, in ibid., pp. 94-96.

"Who are you/me?" tr. Aveling, in Westerly, 4 (Dec. 1976), pp. 46-47.

Tak ada apa-apa di sini

"Empty," tr. Aveling, in Arjuna, p. 72.

"There is nothing here," tr. Hilgers-Hesse, in "Some Thoughts," p. 14 (BT).

The 27th crisis "The 27th crisis," tr. Aveling, in Arjuna, pp. 84-86.

- "After noisy rebellion," tr. Aveling, in ibid., pp. 63-66.

- "I sort of understand," tr. Harry Aveling, in Murdoch News, 3, 1 (Autumn $1975[?])$, p. 8.

"I sort of understand," tr. Aveling, in Arjuna, pp. 92-93.

"I sort of understand," tr. Aveling, in Westerly, 4 (Dec. 1976), pp. 49-50.

. "They say," tr. Aveling, in Arjuna, pp. 79-80.

- "You're there because of twelve faceless men," tr. Aveling, in ibid., pp. 61-62.

DARSJAF Rachman

. "Servant," tr. Hurustiati Subandrio, in Asian Horizon, 1, 1 (Spring 1948), p. 48 .

DHARTA, A. S.

Rukmanda "Rukmanda," tr. Bintang Suradi, in CPIP, p. 35.

. "Tidings from the party," tr. Bintang Suradi, in ibid., p. 36.

DIAT, Akhu

$(((($ plung $))))$ " $(((($ plung $)))), "$ tr. by the poet, in Diat, Four Poems.

Ruh kecil "Small soul," tr. James S. Holmes with the poet, in ibid. (BT).

Syair ke kubur "Ballad to a grave," tr. James S. Holmes with the poet, in ibid. (BT). 
DIAT, Akhu (continued)

. "In water is water is fish is gill is air is," tr. by the poet, with the assistance of James S. Holmes, in ibid.

DJATI

- "Freedom absolute," tr. Ali, in Flaming Earth, p. 14.

DJOEHANA, Mohammad Akbar

. "Free Indonesia," tr. Ali, in ibid., p. 15.

- "Poet maudit" [sic], tr. Ali, in ibid., p. 16.

DJUNASIEN, Muhamed see ASIEN

DODONG Djiwapradja

- "Challenge," tr. Bintang Suradi, in CPIP, p. 43.

"Challenge," tr. Bintang Suradi, in Raffel, Development, p. 144.

- "Death," tr. Bintang Suradi, in CPIP, p. 42.

- "The hero on the hill," tr. Bintang Suradi, in ibid., p. 41.

DULLAH

. "To fifteen friends," tr. Ali, in Flaming Earth, p. 17.

EFFENDI, Rustam see RUSTAM Effendi

FERDY, Samuel

Malia lehi "Malia lehi," tr. Bintang Suradi, in CPIP, p. 44.

GUNAWAN, Basuki see BASUKI Gunawan

GOENAWAN Mohamad

Asmaradana

"Asmaradana," tr. Aveling, in Translations, p. 53.

"Asmaradana," tr. Aveling, in Tenggara, 6 (1973), pp. 50-51 (BT).

"Asmaradana," tr. Aveling, in Goenawan, p. 10 (BT).

"Asmaradana," tr. Aveling, in CIP, pp. 218-19.

Di kota itu, kata orang, gerimis telah jadi logam

"It is a town, so they say, in which the rain has become lead," tr. Aveling, in Translations, p. 52 .

"It is a town, so they say, in which the rain has become brass," tr. Aveling, in Goenawan, p. 8 (BT).

"It is a town, so they say, in which the rain has become lead," tr. Aveling, in CIP, pp. 214-15 (BT).

Di muka djendela

"In front of the window," tr. Ida Noor, in Solidarity, 3, 9 (Sept. 1968), p. 19.

"In front of the window," tr. Raffel, in Development, pp. 154-55.

Dingin tak tercatat

"Cold unregistered," tr. Aveling, in Translations, p. 50.

"Cold unregistered," tr. Aveling, in Goenawan, p. 4 (BT).

"Cold unregistered," tr. Aveling, in CIP, pp. 198-99 (BT).

Dongeng sebelum tidur

"A tale before sleep," tr. Aveling, in Translations, p. 54.

"A tale before sleep," tr. Aveling, in CIP, pp. 200-201 (BT).

Kwatrin musim gugur

"Autumn quatrains," tr. Aveling, in Translations, p. 49.

"Autumn quatrains," tr. Aveling, in Goenawan, p. 3 (BT).

"Autumn quatrains," tr. Aveling, in CIP, pp. 210-11 (BT).

Nina-bobok

"Lullaby," tr. Aveling, in Translations, p. 47.

"Lullaby," tr. Aveling, in CIP, pp. 202-3 (BT). 
GOENAWAN Mohamad (continued)

Ranjang pengantin, Kopenhagen

"Bridal bed, Copenhagen," tr. Aveling, in Translations, pp. 50-51.

Riwayat

"Bridal bed, Copenhagen," tr. Aveling, in CIP, pp. 212-13 (BT).

"Story," tr. Aveling, in Translations, p. 47.

"Story," tr. Aveling, in CIP, pp. 204-5 (BT).

Senja pun jadi kecil, kota pun jadi putih

(English translation untitled), tr. Aveling, in his tr. of Abdul Hadi's article [no Indonesian title or place of publication], "Recent Indonesian Poetry: Flowers of Evil," in 20th Century, 28, 4 (Winter 1974), p. 342.

"Twilight fades the city white," tr. Aveling, in CIP, pp. 206-7 (BT).

Tentang seorang yang terbunuh di sekitar hari pemilihan umum

"A man murdered near the day of the Indonesian general elections," tr. Aveling, in Translations, pp. 51-52.

"A man murdered near the day of the Indonesian general elections," tr. Aveling, in Tenggara, 6 (1973), pp. 52-53 (BT).

"A man murdered near the day of the general elections," tr. Aveling, in Goenawan, p. 7 (BT).

"A man murdered near the day of the Indonesian general elections," tr. Aveling, in CIP, pp. 214-15 (BT).

Waktu adalah mesin hitung, cintaku [originally untitled] "Time is a calculating machine, my love," tr. Muhammad Haji Salleh, in Tenggara, 7 (1975), pp. 10-11 (BT).

$\mathrm{Z} \quad \mathrm{Z}, " \mathrm{tr}$. Aveling, in Translations, p. 48.

"Z," tr. Aveling, in Goenawan, p. 1 (BT).

"Z," tr. Aveling, in CIP, pp. 208-9 (BT).

. "Expatriate," tr. Raffel, in Development, p. 154.

HADI, Asmara see ASMARA Hadi

HADI, S.

. "Lonely night," tr. Bintang Suradi, in CPIP, p. 47.

"My father," tr. Bintang Suradi, in ibid., p. 48.

HADI Sosrodanukusumo

. "Of things to come," tr. Bintang Suradi, in ibid., p. 46.

- "Song," tr. Bintang Suradi, in ibid., p. 45.

HADI W. M. (Widji Muthari), Abdul see ABDUL Hadi W. M.

HAMZAH, Amir see AMIR Hamzah

HARAHAP, Bandaharo

Tak seorang berniat pulang "No one shall return," tr. Bintang Suradi, in CPIP, p. 39 .

Tumbang "Fallen in battle," tr. Bintang Suradi, in ibid., pp. 37-38.

Ziarah "At the graveside," tr. Raffel, in Development, p. 145.

- "After Panmunjom," tr. Bintang Suradi, in CPIP, p. 40.

"After Panmunjom," tr. Bintang Suradi, in Indonesia Sings, p. 7.

. "He was murdered," tr. Bintang Suradi, in We All Are, pp. 7-8.

HARTOJO Andangdjaja

Sajak "Poem," tr. Hilgers-Hesse, in "Some Thoughts," p. 11 (BT).

HASJMI, A(li)

Bintang "Stars," tr. Sularko (?), in Usman, "Introduction," p. 32.

HATMOHARSOIO, Louise Walujati see WALUJATI, Louise 
HATTA, Mohammad

Beranta indera "Divine celestial (? dawn)," tr. Teeuw, in $M I L, p p .11,257$ (BT).

HERATZ, Toeti see TOETI Heratz

HUTA-URUK

Dimuka katja "Before the mirror," tr. Sularko (?), in Usman, "Introduction," p. 36.

IS

- "Menteng at night," tr. Ali, in Flaming Earth, p. 18.

ISMAIL, Taufiq see TAUFIQ Ismail

ISMAIL, Usmar see USMAR Ismail

JOKE Moeljono see MOELJONO, Joke

KARDJO, Wing see WING Kardjo

KART AHADIMADJA, Aoh

Mendjelang hidup "Coming to life," tr. Sularko (?), in Usman, "Introduction," p. 34 .

KARTAKUSUMA, Mh. Rustandi see RUSTANDI Kartakusuma, Mh.

KERTAPATI, Rukiah see RUKIAH Kertapati

KIRNANTO, Slamet see SLAMET Kirnanto

KRISHNA Mustajab

. "Serenade 77," tr. K. Mustajab \& E. Ritchie, in "Outside the Museum: Contemporary Writings, Vol. I," ed. Fred Wolven (No. 28/special issue of Ann Arbor Review, 1978), p. 47.

. "Shadow-chase," tr. E. Ritchie \& K. Mustajab, in ibid., p. 46.

KUNTJAHJO, S. W.

- "Dawn over Palau," tr. Bintang Suradi, in Indonesia Sings, p. 10.

KUSNI Sulang

Sampit "Sampit," tr. Bintang Suradi, in CPIP, p. 67.

. "The fishermen of Katingan," tr. Bintang Suradi, in ibid., pp. 68-70.

MOELJONO, Joke

Pemuda

"Pemuda," tr. Ali, in Flaming Earth, pp. 22-23.

"Pemuda," tr. Ali, in Wigmore, Span, pp. 164-65.

"Freedom fighter," tr. Beier, in Only Dust, pp. 22-23.

Sasanamoelija

"Palace of the princes," tr. Ali, in Flaming Earth, p. 21.

"Palace of the princes," tr. Beier, in Only Dust, p. 19.

. "In alien land," tr. James S. Holmes, in POI, p. 105.

. "The graveyard," tr. Ali, in Flaming Earth, p. 20.

MUSTAJAB, Krishna see KRISHNA Mustajab

NAZOLA, Ali S. see ALI S. Nazola

NJOTO

. "Haiku variations," tr. Bintang Suradi, in CPIP, pp. 53-54.

"Haiku variations," tr. Bintang Suradi, in Indonesia Sings, pp. 11-12.

- "Scarlet red," tr. Bintang Suradi, in We All Are, p. 9.

"Scarlet red," tr. Bintang Suradi, in CPIP, p. 52. 
NURDIN Abd., M.

. "The false," tr. Oentoeng Soebroto and Robert Chapman, in Wigmore, Span, pp. 57-58.

NOERSJAMSOE

- "The embroidery," tr. Ali, in Flaming Earth, p. 24.

"The embroidery," tr. ?, in SIL, title page.

. "Only one tint," tr. Hurustiati Subandrio, in Asian Horizon, 1, 1 (Spring 1948), p. 48.

OKA, Putu

Bali "Bali," tr. Bintang Suradi, in CPIP, p. 55.

- "Life," tr. Bintang Suradi, in ibid., p. 56.

PANÉ, Armijn

Djiwa telah meranggas

"A withered soul," tr. Raffel, in Development, p. 62.

"My soul is withered," tr. Teeuw, in MIL, pp. 80, 262 (BT).

Hamba buruh "A wage slave," tr. Raffel, in Development, p. 62.

Tiada kata lain "No other words," tr. Raffel, in ibid., pp. 62-63.

PANÉ, Sanusi

Bersila "Sitting cross-legged," tr. Raffel, in Development, p. 40.

Betapa kami tidakkan suka "How could we fail to be happy?" $\operatorname{tr}$. Teeuw, in MIL, pp. 25, 259 (BT).

Biarkan daku "Permit me . . . ," tr. Teeuw, in ibid., pp. 24, 259 (BT).

Damai "Peace," tr. Raffel, in Development, p. 43.

Dibawa gelombang "On the waves," tr. Raffel, in ibid., pp. 40-41, 217.

Do'a "Prayer," tr. Teeuw, in MIL, pp. 26, 260 (BT).

Kembang melati (English translation untitled), tr. Foulcher, in "PSMP," p. 57 (BT). Mentjari

"Seeking," tr. Raffel, in Development, pp. 44, 216-17.

"Searching" (English translation originally untitled), tr. M. Balfas, in "The

Three Seasons of Sitor Situmorang," RIMA, 7, 2 (July-December 1973), pp. 70-71 (BT).

Menumbuk padi "Pounding rice," tr. Raffel, in Development, p. 43.

$\overline{\mathrm{Nasib}}$

"Fate," tr. Raffel, in "Beginnings," pp. 70-71.

"Fate," tr. Raffel, in Development, pp. 41-42.

Sadjak "Poem," tr. Teeuw, in MIL, pp. 21, 258-59 (BT).

Sebagai merpati (English translation untitled), tr. Foulcher, in "PSMP,"p. 54 (BT). Tedja

"Sunset glow," tr. Raffel, in "Beginnings," pp. 69-70.

"Sunset glow," tr. Raffel, in Development, p. 42.

Tempat bahagia "The place of happiness," tr. Moerdowo, Sociological Aspects, p. 6. Tjandi "Hindu monument," tr. Raffel, in Development, p. 39.

Tjandi Mendut

"The Mendut temple," tr. Moerdowo, in Sociological Aspects, pp. 7-8.

"Tjandi Mendut," tr. Teeuw, in MIL, pp. 26, 259 (BT).

- "At the Prambanan Temple," tr. Moerdowo, in Sociological Aspects, p. 7.

PIEK Ardijanto Suprijadi

. "The hungry," tr. Bintang Suradi, in CPIP, p. 75.

. "Young man," tr. Bintang Suradi, in ibid., p. 74. 
PRIYONO

Kita adalah "We are," tr. Candyce Golis, Frances Hayes, Bana Kartasasmita, and Toenggoel Siagian, in Boen Sri Oemarjati, "Tendencies in the Direction of Contemporary Indonesian Literature: Poetry or Drama?" (Madison: Center for Southeast Asian Studies, University of Wisconsin, 1974), p. 106.

PUTU Oka see OKA, Putu

RACHMAN, Darsjaf see DARSJAF Rachman

RAMADHAN K. H.

Seruling di pasar ipis, merdu "Flutes on this sands are melodious" (originally untitled), tr. Salleh, in Tradition \& Change, pp. 106-7 (BT).

- "Songs of praise to Sunda, West Java," tr. Harry Aveling, in Solidarity, 8, 7 (Jan. 1974), pp. 57-60.

- Songs of praise to Sunda, West Java, tr. Aveling (n.p., n.d.), 161.

RASUANTO, Bur see BUR Rasuanto

RENDRA, W. S.

A landscape for dear Victor [orig. title in English] "A landscape for dear Victor," tr. Raffel, in Ballads \& Blues, pp. 142-45 (BT).

Amsal seorang santu

"A saint," tr. Raffel, in Development, pp. 187-89.

"A saint," tr. Raffel (?), in Aveling, Rendra.

"A saint," tr. Raffel, in Rendra, Ballads \& Blues, pp. 166-71 (BT).

Anak jang angkuh "The proud child," tr. May, in ibid., pp. 32-35 (BT).

Baji didasar kali "Baby at the bottom of the river," tr. Aveling, in ibid., pp. $100-101$ (BT).

Ballada ibu jang dibunuh "Ballad of the murdered mother," tr. Raffel, in ibid., pp. 28-31 (BT).

Ballada Kasan dan Patima "Ballad of Kasan and Patima," tr. Aveling, in ibid., pp. 2-7 (BT).

Ballada lelaki jang luka "Ballad of the wounded man," tr. Raffel, in ibid., pp. 14-17 (BT).

Ballada lelaki-lelaki tanah kapur

"Ballad of the men of limestone soil," tr. Derwent May, in "Chapbook," pp. 19-20.

"Ballad of the men of the limestone soil," tr. May, in Raffel, AMIP, pp. 144-45.

"Ballad of the men of the limestone soil," tr. May, in José, Asian PEN, pp. 165-66.

"Ballad of the men of the limestone soil," tr. May, in Raffel, Development, pp. 169-70.

"Ballad of the men of the limestone soil," tr. May, in Rendra, Ballads \& Blues, pp. 8-11.

Ballada penjaliban

"Ballad of the crucifixion," tr. Harry Aveling, in his "The Religious Verse of W. S. Rendra," in Solidarity, 5, 9 (Sept. 1970), pp. 51-52.

"Ballad of the crucifixion," tr. Raffel, in Development, pp. 174-75.

"Ballad of the crucifixion," tr. Raffel, in Rendra, Ballads \& Blues, pp. 26-29 (BT).

Ballada petualang

"Ballad of the wanderer," tr. Aveling, in Rendra.

"Ballad of the wanderer," tr. Raffel, in Ballads \& Blues, pp. 10-13 (BT).

Ballada terbunuhnja Atmo Karpo "Ballad of the killing of Atmo Karpo," tr. May, in ibid., pp. 16-19 (BT). 
RENDRA, W. S. (continued)

Batu hitam

"Black rocks," tr. Burton Raffel, in East-West Review, 2 (1966), p. 227.

"Black rocks," tr. Raffel, in Rendra, Ballads \& Blues, pp. 72-73 (BT).

Bersatulah pelatjur-pelatjur kota Djakarta

"Prostitutes of Jakarta, unite!" tr. Harry Aveling, in Tenggara, 2,2 (1968), pp. 20-25.

"Prostitutes of Djakarta--unite!" tr. Aveling, in Indonesian Poet, pp. 14-16.

"Prostitutes of Jakarta--unite!" tr. Aveling, in Rendra.

"Prostitutes of Jakarta--unite!" tr. Aveling, in Rendra, Ballads \& Blues, pp. 210-17 (BT).

"Prostitutes of Jakarta--unite!" tr. Aveling, in CIP, pp. 26-33 (BT).

"Prostitutes of Jakarta--unite!" tr. Aveling, in Nation Review [Canberra], 8,38 (July $7-13,1978$ ), p. 9.

"Prostitutes of Djakarta unite!" tr. A. H. Johns, in Quadrant, 61, 13, 5

(Sept.-Oct. 1969), pp. 39-41.

Blues untuk Bonnie

"Blues for Bonnie," tr. Aveling, in Indonesian Poet, pp. 6-8.

"Blues for Bonnie," tr. Aveling, in Rendra, Ballads \& Blues, pp. 192-99 (BT).

Bulan kota Djakarta "Moon over Jakarta," tr. Raffel, in ibid., pp. 86-87 (BT).

Bumi hangus

"Scorched earth," tr. Raffel, in Development, p. 177.

"Scorched earth," tr. Raffel, in Rendra, Ballads \& Blues, pp. 76-77 (BT).

Bunga gugur "Flowers fall," tr. Aveling, in ibid., pp. 40-41 (BT).

Burung hitam "Black bird," tr. Raffel, in ibid., pp. 74-75 (BT).

Burung terbakar "Bird of fire," tr. Raffel, in ibid., pp. 84-85 (BT).

Chotbah

"Sermon," tr. Aveling, in "Melody," pp. 59-64.

"Sermon," tr. Aveling, in Poetry Reading, pp. 18-19.

"Sermon," tr. Aveling, in Indonesian Poet, pp. 27-32.

"Sermon," tr. Aveling, in Rendra, Ballads \& Blues, pp. 244-57 (BT).

"Sermon," tr. Aveling, in CIP, pp. 2-15 (BT).

Datanglah, ya Allah

"Come, oh God," tr. Harry G. Aveling, in his "The Religious Verse of W. S.

Rendra," in Solidarity, 5, 9 (Sept. 1970), p. 54.

"Come, oh God," tr. Aveling, in Rendra, Ballads \& Blues, pp. 176-77 (BT).

Dimedja makan

"At the table," tr. Raffel, in Development, p. 173.

"At the table," tr. Raffel, in Rendra, Ballads \& Blues, pp. 36-37 (BT).

Djustru pada achir tahun

"Just at the end of a year," tr. Raffel, in Development, p. 180.

"Just at the end of a year," tr. Raffel, in Rendra, Ballads \& Blues, pp. 118121 (BT).

Doa malam "Evening prayer," tr. Aveling, in ibid., pp. 158-61 (BT).

Doa orang lapar "Prayer of the hungry," tr. Aveling, in ibid., pp. 172-75 (BT). Dongeng pahlawan

"Once upon a time a hero . . . ," tr. Raffel, in Development, p. 177.

"Once upon a time a hero ...." tr. Raffel, in Rendra, Ballads \& Blues, pp. 76-77 (BT).

Episode

"Episode," tr. Raffel, in Development, pp. 176-77.

"Episode," tr. Raffel, in Rendra, Ballads \& Blues, pp. 54-55 (BT).

Geredja Ostankino, Moskwa

"Ostankino Church, Moscow," tr. Raffel, in Development, p. 182.

"Ostankino Church, Moscow," tr. Raffel, in Rendra, Ballads \& Blues, pp. 136-37 (BT). 
RENDRA, W. S. (continued)

Gerilja "Guerrilla," tr. Aveling, in ibid., pp. 18-21 (BT).

Gugur "Fallen," tr. Raffel, in ibid., pp. 94-97 (BT).

Ho Liang telah pergi "Ho Liang is gone," tr. Raffel, in ibid., pp. 106-9 (BT).

Hongkong

"Hongkong," tr. Raffel, in Development, p. 185.

"Hongkong," tr. Raffel, in Rendra, Ballads \& Blues, pp. 140-43 (BT).

Hotel Aichun, Canton

"Aichun Hotel, Canton," tr. Raffel, in Development, p. 184.

"Aichun Hotel, Canton," tr. Raffel, in Rendra, Ballads \& Blues, pp. 138-41 (BT).

Hotel Internasional, Pyongyang

"International Hotel, Pyongyang," tr. Raffel, in Development, pp. 183-84.

"International Hotel, Pyongyang," tr. Raffel, in Rendra, Ballads \& Blues, pp. 134-35 (BT).

Ia bernjanji dalam hudjan "She's singing in the rain," tr. Raffel, in ibid., pp. 102-3 (BT).

Ia telah pergi

"He's gone," tr. Raffel, in Development, pp. 179-80.

"He's gone," tr. Raffel, in Rendra, Ballads \& Blues, pp. 78-79 (BT).

Kali hitam "Black river," tr. Raffel, in ibid., pp. 72-73 (BT).

Kami pergi malam-malam "We go late at night," tr. Aveling, in ibid., pp. 120-23 (BT).

"We go by night," tr. Harry Aveling, in his "The Religious Verse of W. S.

Rendra," in Solidarity, 5, 9 (Sept. 1970), p. 52.

"We go late at night," tr. Aveling, in Rendra, Ballads \& Blues, pp. 120-23 (BT).

Kenangan dan kesepian "Memories and solitudes," tr. Raffel, in ibid., pp. 106-7 (BT).

Kepada M.G.

"For M.G.," tr. Aveling, in Indonesian Poet, pp. 2-3.

"For M.G.," tr. Aveling, in Rendra, Ballads \& Blues, pp. 184-89 (BT).

"For M.G.," tr. Aveling, in CIP, pp. 70-73 (BT).

Kesaksian tahun 1967

"Testimony of 1967," tr. Aveling, in Indonesian Poet, p. 13.

"Testimony, 1967," tr. Aveling, in Rendra, Ballads \& Blues, pp. 208-9 (BT).

Kojan jang malang

"Kojan the unfortunate," tr. Raffel, in Development, pp. 171-72.

"Kojan the unfortunate," tr. Raffel (?), in Aveling, Rendra.

"Koyan the unfortunate," tr. Raffel, in Rendra, Ballads \& Blues, pp. 24-25 (BT).

Kupanggili namamu

"I call your name," tr. Aveling, in Indonesian Poet, pp. 1-2.

"I call your name," tr. Aveling, in Rendra.

"I call your name," tr. Aveling, in Rendra, Ballads \& Blues, pp. 182-85 (BT).

"I call your name," tr. Aveling, in CIP, pp. 66-69 (BT).

"I call your name," tr. A. H. Johns, Quadrant, 61, 13, 5 (Sept.-Oct. 1969), pp. $39-41$.

Lagu angin

"The wind's song," tr. Burton Raffel, in East-West Review, 2 (1966), p. 228.

"The wind's song," tr. Raffel, in Rendra, Ballads \& Blues, pp. 74-75 (BT).

Lagu ibu "Mother's song," tr. Raffel, in ibid., pp. 74-75 (BT).

Lagu serdadu "Soldier's song," tr. Aveling, in ibid., pp. 76-77 (BT).

Lelaki sendirian "Man, alone," tr. Raffel, in ibid., pp. 90-91 (BT).

Malaikat di Gereja St. Josef "An angel at St. Joseph's Church," tr. Raffel, in ibid., pp. 64-65 (BT). 
RENDRA, W. S. (continued)

Malaikat-malaikat ketjil "Little angels," tr. Raffel, in ibid., pp. 98-99 (BT).

Malam jahat "Evil night," tr. Raffel, in ioid., pp. 82-83 (BT).

Mantjuria

"Manchuria," tr. Raffel, in Development, p. 183.

"Manchuria," tr. Raffel, in Rendra, Ballads \& Blues, pp. 132-33 (BT).

Masmur mawar "Rose psalm," tr. Aveling, in ibid., pp. 178-79 (BT).

Masmur pagi "Morning psalm," tr. Aveling, in ibid., pp. 156-59 (BT).

Mata andjing "Dog eyes," tr. Raffel, in ibid., pp. 82-83 (BT).

Mata hitam "Black eyes," tr. Raffel, in ibid., pp. 72-73 (BT).

Nenek jang tersia bersunji diri "The useless grandmother keeps to herself," tr.

Raffel, in ibid., pp. 108-9 (BT).

Nina bobok bagi pengantin

"Lullaby for a bride," tr. Raffel (?), in Aveling, Rendra.

"Lullaby for a bride," tr. Raffel, in Rendra, Ballads \& Blues, pp. 66-69 (BT).

Njanjian angsa

"Swan song," tr. Harry Haveling, in Tenggara, 2, 2 (1968), pp. 4-21.

"Swan song," tr. Aveling, in Indonesian Poet, pp. 20-27.

"Swan song," tr. Aveling, in Rendra.

"Swan song," tr. Aveling, in Rendra, Ballads \& Blues, pp. 226-43 (BT).

"Swan song," tr. Aveling, in CIP, pp. 46-65 (BT).

Njanjian duniawi

"A worldly song," tr. Aveling, in Indonesian Poet, p. 4.

"A worldly song," tr. Aveling, in Rendra, Ballads \& Blues, pp. 188-91 (BT).

"A worldly song," tr. Aveling, in CIP, pp. 42-43 (BT).

Njanjian Fatima untuk Suto

"Fatima's song for Suto," tr. Aveling, in Indonesian Poet, p. 5.

"Fatima's song for Suto," tr. Aveling, in Rendra, Ballads \& Blues, pp. 190191 (BT).

Njanjian perempuan di kali "Song of a woman in the river," tr. Raffel, in ibid., pp. 104-5 (BT).

Njanjian Suto untuk Fatima

"Suto's song for Fatima," tr. Aveling, in Indonesian Poet, p. 5.

"Suto's song for Fatima," tr. Aveling, in Rendra, Ballads \& Blues, pp. 190191 (BT).

"Suto's song for Fatima," tr. Aveling, in CIP, pp. 74-75 (BT).

Pelarian sia-sia "Running for nothing," tr. Raffel, in Rendra, Ballads \& Blues, pp. 114-17 (BT).

Pemandangan sendjakala

"Twilight view," tr. Aveling, in Indonesian Poet, p. 13.

"A view at dusk," tr. Aveling, in Rendra.

"Twilight view," tr. Aveling, in Rendra, Ballads \& Blues, pp. 210-11 (BT).

"Twilight view," tr. Aveling, in CIP, pp. 44-45 (BT).

"A view at dusk," tr. A. H. Johns, in Quadrant, 61, 13, 5 (Sept.-Oct. 1969), p. 38 .

Penunggu gunung berapi "Guardian of the volcano," tr. Raffel, in Rendra, Ballads \& Blues, pp. 110 - 13 (BT).

Perbuatan serong "The wrong thing to do," tr. Raffel, in ibid., pp. 88-89 (BT).

Perempuan jang menunggu "Woman, waiting," tr. Raffel, in ibid., pp. 80-81 (BT).

Pertemuan di pinggir kali "Meeting at the river bank," tr. Raffel, in ibid., pp. $110-11$ (BT).

Pesan pentjopet kepada patjarnja

"A pickpocket's advice to his mistress," tr. Harry Aveling, in Tenggara, 2,2 (1968), pp. 26-31. 
RENDRA, W. S. (continued)

Pesan pentjopet kepada patjarnja (continued)

"A pick-pocket's advice to his mistress," tr. Aveling, in Indonesian Poet, pp. 17-19.

"A pick-pocket's advice to his mistress," tr. Aveling, in Rendra, Ballads \& Blues, pp. 218-25 (BT).

"A pick-pocket's advice to his mistress," tr. Aveling, in CIP, pp. 34-41 (BT).

"The pickpocket's message to his girl," tr. M. Hidayat, in Solidarity, 3, 9 (Sept. 1968), pp. 61-63.

Petualang "Wanderer," tr. Raffel, in Rendra, Ballads \& Blues, pp. 118-19 (BT). Pisau didjalan

"Knife in the road," tr. Burton Raffel, in East-West View, 2 (1966), p. 229.

"Knife in the road," tr. Raffel, in Rendra, Ballads \& Blues, pp. 92-93 (BT).

Randjang bulan, randjang pengantin

"The moon's bed, the bride's bed," tr. Raffel, in Development, pp. 178-79.

"The moon's bed, the bride's bed," tr. Raffel (?), in Aveling, Rendra.

"The moon's bed, the bride's bed," tr. Raffel, in Rendra, Ballads \& Blues, pp. 64-67 (BT).

Remang-remang

"Darkness," tr. Raffel (?), in Aveling, Rendra.

"Darkness," tr. Raffel, in Rendra, Ballads \& Blues, pp. 84-85 (BT).

Rick dari Corona

"Rick from Corona," tr. Aveling, in Indonesian Poet, pp. 9-12.

"Rick from Corona," tr. Aveling, in "Melody," pp. 56-59.

"Rick from Corona," tr. Aveling, in Rendra, Ballads \& Blues, pp. 198-207 (BT).

"Rick from Corona," tr. Aveling, in CIP, pp. 16-25 (BT).

Rumpun alang-alang

"Tall weeds,"tr. Burton Raffel, in East-West Review, 2 (1966), p. 228.

"Tall weeds," tr. Raffel, in Rendra, Ballads \& Blues, pp. 82-83 (BT).

Sebuah dunia jang marah "A world of anger," tr. Aveling, in ibid., pp. 160-65 (BT). Serenada biru

"Blue serenade," tr. Raffel, in ibid., pp. 52-53 (BT).

"(Serenade in blue)" [translation originally untitled], $\mathrm{tr}$. Salleh, in Tradition \& Change, pp. 112-13 (BT).

Serenada hidjau

"Green serenade," tr. Burton Raffel, in East-West Review, 2 (1966), p. 230.

"Green serenade," tr. Raffel, in Rendra, Ballads \& Blues, pp. 50-51 (BT).

Serenada kelabu

"Grey serenade," tr. Raffel, in ibid., pp. 60-61 (BT).

"(Serenade in gray)" [translation originally untitled], tr. Salleh, in Tradition \& Change, pp. 113-14 (BT).

Serenada putih "White serenade," tr. Raffel, in Rendra, Ballads \& Blues, pp. 58-61 (BT).

Serenada violet

"Violet serenade," tr. Raffel, in Development, p. 178.

"Violet serenade," tr. Raffel (?), in Aveling, Rendra.

"Violet serenade," tr. Raffel, in Rendra, Ballads \& Blues, pp. 56-57 (BT).

Setelah pengakuan dosa "After confession," tr. Raffel, in ibid., pp. 78-79 (BT).

Spada "Who goes there?" tr. Raffel, in ibid., pp. 80-81 (BT).

Sungai Moskwa

"The Moscow River," tr. Raffel, in Development, pp. 181-82.

"The Moscow River," tr. Raffel, in Rendra, Ballads \& Blues, pp. 136-37 (BT).

Surat seorang isteri "A wife's letter," tr. Aveling, in ibid., pp. 148-53 (BT). 
RENDRA, W. S. (continued)

Surat tjinta

"Love letter," tr. Raffel, in Development, pp. 175-76.

"Love letter," tr. Raffel (?), in Aveling, Rendra.

"Love letter," tr. Raffel, in Rendra, Ballads \& Blues, pp. 44-49 (BT).

Tahanan

"Prisoner," tr. Aveling, in ibid., pp. 20-23 (BT).

"Prisoner," tr. Moerdowo, in Sociological Aspects, p. 13.

"Captive," tr. Teeuw, in $M I L$, pp. 234-35, 270 (BT).

Tak bisa kulupakan "I cannot forget," tr. Raffel, in Rendra, Ballads \& Blues, pp. 84-85 (BT).

Tangis "Crying," tr. Raffel, in ibid., pp. 30-33 (BT).

The dying swan "The dying swan," tr. Aveling, in ibid., pp. 126-29 (BT).

Tingkat lebih "Higher state," tr. Raffel, in ibid., pp. 112-13 (BT).

Undangan "Invitation," tr. Raffel, in ibid., pp. 62-63 (BT).

Wadjah dunia jang pertama "The world's first face," tr. Raffel, in ibid., pp. 68-71 (BT).

Waktu "Time," tr. Raffel, in ibid., pp. 78-79 (BT).

. "I hear voices," tr. Harry Aveling, in Hemisphere, 18, 10 (Oct. 1974), p. 17.

. "In Sydney," tr. Harry Aveling, in ibid. , p. 16.

"Little sister Narti," tr. Burton Raffel, in Shimer, Mentor Book, p. 72.

"Love song," tr. Harry Aveling, in Hemisphere, 18, 10 (Oct. 1974), pp. 16-17.

"Song of Bali," tr. Harry Aveling, in Westerly, 24, 3 (Sept. 1979), pp. 67-68.

"Stanzas at noon," tr. Leila Petterson, in Indonesia, special issue of Westerly, Oct. $1966, p .26$.

- State of Emergency, tr. Suami Anand Haridas [Harry Aveling] (Sydney \& Los Angeles: Wild \& Wooley, 1980).

RISAKOTTA, Ferdinand Lodewijk

- "Anniversary poetry," tr. Bintang Suradi, in CPIP, p. 60.

- "The grave on a hillside," tr. Bintang Suradi, in ibid., pp. 57-58.

- "Yesterday and today," tr. Bintang Suradi, in ibid., p. 59.

"Yesterday and today," tr. Bintang Suradi, in Indonesia Sings, pp. 13-14.

RIVAI Apin

Dari dua dunia belum sudah

"Between two worlds," tr. Ali, in Flaming Earth, pp. 3-4.

"Between two worlds," tr. Ahmed Ali \& Idham, in POI, p. 163.

"From two as yet unfinished worlds," tr. Aveling, in "Poetry \& the Indonesian Revolution," p. 44.

"Between two unfinished worlds," tr. Jean Kennedy \& Burton Raffel, in Raffel, $A M I P$, pp. 72-73.

"Between two unfinished worlds," tr. Kennedy \& Raffel, in Raffel, Development, pp. 117-18.

"Of two worlds still incomplete," tr. Jean Kennedy, in Raffel, Forked Tongue, pp. 87-88.

"Between two unfinished worlds," tr. Kennedy \& Raffel, in ibid., pp. 88-89.

Elegi

"Elegy," tr. Ali, in Flaming Earth, pp. 1-2.

"Elegy," tr. Ali, in $S / L, p .11$.

"Elegy," tr. Burton Raffel \& Nurdin Salam, in Echols, IWT, p. 63.

"Elegy," $\mathrm{tr}$. Bintang Suradi, in CPIP, pp. 26-27.

Kebebasan "Independence," tr. Burton Raffel \& Nurdin Salam, in Raffel, Development, p. 119.

Kepada pemimpin "To the leader," tr. Sularko, in Usman, "Introduction," p. 37. 
RIVAI Apin (continued)

Melalui siang menembus malam

"Pass through day: penetrate the night," tr. Harry Aveling, in "Indonesian Wasteland: The Verse of Rivai Apin," in Search for Identity: Modern Literature and the Creative Arts in Asia, ed. A. R. David (Sydney: Angus and Robertson, 1974), pp. 165-70 (BT).

"Night stabs through the day," tr. Burton Raffel \& Nurdin Salam, in Raffel, Development, pp. 119-20.

Peking

"Peking," tr. Bintang Suradi, in CPIP, p. 28.

"Peking," tr. Bintang Suradi, in Indonesia Sings, p. 4.

"Peking," tr. Raffel, in Development, p. 120.

Puteri bening "A pure princess," tr. Raffel, in ibid., pp. 116-17.

Putusan tjita "Broken ideals," tr. Raffel, in ibid., p. 116.

Tugu "A monument," tr. Burton Raffel \& Nurdin Salam, in Raffel, Development, p. 115.

- "Poems for my beloved," tr. Aveling, in Lachesis (April 1968), p. 16.

- "The anchor chain is broken," tr. Bintang Suradi, in CPIP, p. 25.

. "The wanderer," tr. Ali, in Flaming Earth, p. 5.

"The wanderer," tr. ?, in Wigmore, Span, p. 125.

ROSIDI, Ajip see AJIP Rosidi

RUKIAH Kertapati

- "Indictment," tr. Bintang Suradi, in CPIP, pp. 49-50.

. "The child of a worker," tr. Bintang Suradi, in ibid., p. 51.

RUSTAM Effendi

Air mata

"Tears," tr. Raffel, in "Beginnings," p. 72.

"Tears," tr. Raffel, in Development, p. 53.

Bukan beta bidjak berperi

"I'm not a clever talker," tr. Keith Foulcher, in "Some Considerations on the Approach to Modern Indonesian Literature," RIMA, 2 (April-June 1968), pp. 29-36 (BT).

"I'm not much of a talker," tr. Raffel, in "Beginnings," p. 73.

"I'm not much of a talker," tr. Raffel, in Development, pp. 52, 215.

Kekajaan Tuhan "God's power," tr. Raffel, in ibid., pp. 53-54.

Kepada yang bergurau (English translation untitled), tr. Foulcher, in "PMSP," p. 51 (BT).

Lengang (English translation untitled), tr. Foulcher, in ibid., pp. 49-50 (BT).

Rahsia alam "Nature's secret," tr. Raffel, in Development, pp. 47-48, 50 (BT).

RUSTANDI Kartakusuma, Mh.

Antjaman bengis menggumam dalam awan hitam [originally untitled] "A cruel threat rumbles in the dark clouds," tr. Teeuw, in MIL, pp. 209, 269.

SABARSANTOSO Anantaguna see ANANTAGUNA, Sabarsantoso

SANI, Asrul see ASRUL Sani

SANUSI Pané see PANÉ, Sanusi

SAPARDI Djoko Damono

Dalam doa: II

"In prayer: II," tr. Aveling, in Translations, p. 8.

"In prayer: II," tr. Aveling, in CIP, pp. 244-45 (BT).

Dalam doa: III "In prayer: III," tr. Harry Aveling, in "Indonesian Poetry Today," Hemisphere, 16, 1 (Jan. 1972), p. 10. 
SAPARDI Djoko Damono (continued)

Dalam sakit

"In sickness," tr. Aveling, in "Melody," p. 55.

"In sickness," tr. Aveling, in Poetry Reading, p. 17.

"In sickness," tr. Aveling, in Translations, p. 4.

Djarak

"In sickness," tr. Aveling, in CIP, pp. 230-31 (BT).

(English translation untitled), tr. Aveling, in "Contemporary," p. 102.

"Space," tr. Aveling, in "Melody," p. 53.

"Space," tr. Aveling, in Poetry Reading, p. 17.

"Space," tr. Aveling, in Translations, p. 12.

"Space," tr. Aveling, in CIP, pp. 258-59 (BT).

Dua sadjak dibawah satu kata

[second poem of] "Two poems under the one title," tr. Aveling, in "Melody," p. 54 .

"Two poems under one name II," tr. Aveling, in Poetry Reading, p. 17.

"Two poems with the one title," tr. Aveling, in Translations, p. 10.

"Two poems with one title," tr. Aveling, in CIP, pp. 252-53 (BT).

Gerimis djatuh

"The rain falls," tr. Harry Aveling, in "Indonesian Poetry Today," Hemisphere, 16, 1 (Jan. 1972), p. 10.

"The rain falls," tr. Aveling, in Translations, p. 5.

"The rain falls," tr. Aveling, in CIP, pp. 234-35 (BT).

Gerimis ketjil di Djalan Djakarta, Malang

"A light drizzle in Djakarta Street, Malang," tr. Aveling, in Translations, p. 9.

"A light drizzle in Jakarta Street, Malang," tr. Aveling, in CIP, pp. 250-51 (BT).

Ketika jari-jari bunga terbuka

"As the petals of the flower open," tr. Aveling, in Translations, p. 8.

"As the petals of the flower open," tr. Aveling, in CIP, pp. 246-47 (BT).

Kupandang kelam jang merapat kesisi kita

(English translation untitled), tr. Aveling, in "Melody," p. 55.

"I see the darkness gather around us," tr. Aveling, in Poetry Reading, p. 17.

"I see darkness gathering around us," tr. Aveling, in Translations, p. 11.

(English translation untitled), tr. Aveling, in "Recent Indonesian Poetry:

Flowers of Evil," in 20th Century, 28, 4 (Winter 1974), pp. 342-43.

"I see darkness gathering around us," tr. Aveling, in CIP, pp. 254-55 (BT).

Pada suatu hari nanti

"One day," tr. Aveling, in Translations, p. 7.

Prologue

"One day," tr. Aveling, in CIP, pp. 242-43 (BT).

"Prologue," tr. Aveling, in "Contemporary," p. 103.

"Prologue," tr. Aveling, in Translations, p. 3.

"Prologue," tr. Aveling, in CIP, pp. 222-23 (BT).

Saat sebelum berangkat

(English translation untitled), tr. Aveling, in "Contemporary," p. 103.

"A moment before leaving," tr. Aveling, in "Impressions," pp. 71-72.

"Moment before leaving," tr. Aveling, in Translations, p. 4.

"Moment before leaving," tr. Aveling, in CIP, pp. 228-29 (BT).

Sadjak perkawinan

(English translation untitled), tr. Aveling, in "Contemporary," p. 105.

"Marriage song," tr. Aveling, in "Impressions," p. 72.

"Marriage poem," tr. Aveling, in Translations, p. 9.

"Marriage poem," tr. Aveling, in CIP, pp. 248-49 (BT). 
SAPARDI Djoko Damono (continued)

Sadjak putih

"White poem," tr. Aveling, in "Contemporary," p. 103.

"White poem," tr. Aveling, in "Melody," p. 54.

"White poem," tr. Aveling, in Poetry Reading, p. 17.

"White poem," tr. Aveling, in Translations, p. 3.

"White poem," tr. Aveling, in CIP, pp. 226-27 (BT).

Sebuah taman sore hari

"A park in the afternoon," tr. Aveling, in "Contemporary," p. 104.

"A park in the afternoon," tr. Aveling, in "Melody," p. 55.

"A park in the afternoon," tr. Aveling, in Poetry Reading, p. 17.

"A park in the afternoon," tr. Aveling, in Translations, p. 5.

"A park in the afternoon," tr. Aveling, in Thematic History, p. 54 (BT).

"A park in the afternoon," tr. Aveling, in CIP, pp. 236-37 (BT).

Siapakah engkau

"Who are you," tr. Aveling, in ibid., pp. 224-25 (BT).

"Who are you?" tr. Salleh, in Tradition \& Change, pp. 68-69.

Sonnet X

"Sonnet X," tr. Aveling, in Translations, pp. 11-12.

"Sonnet X," tr. Aveling, in CIP, pp. 256-57 (BT).

Tiba-tiba malam pun risik

"Suddenly night rustles," tr. Aveling, in "Contemporary," p. 104.

"Suddenly night rustles," tr. Aveling, in Translations, p. 5.

"Suddenly night rustles," tr. Aveling, in CIP, pp. 232-33 (BT).

Variasi pada suatu pagi

"Morning variations," tr. Harry Aveling, in Tri-Quarterly [Northwestern

University, Evanston, Ill.], 31 (Fall 1974), p. 26.

"Morning variations," tr. Aveling, in CIP, pp. 260-61 (BT).

Ziarah

"Pilgrimage," tr. Aveling, in Translations, pp. 6-7.

"Pilgrimage," tr. Aveling, in CIP, pp. 238-41 (BT).

- "One morning," tr. Taufiq Ismail, in Solidarity, 3,9 (Sept. 1968), p. 12.

SARIBI, Mohammad

Ibu "Mother," tr. Raffel, in Development, p. 156.

Mohammad "Mohammad," tr. Raffel, in ibid., pp. 155-56.

SISWADI, Sugiarti see SUGIARTI Siswadi

SITUMORANG, Sitor

Algodjo putih telah beraksi "The white executioner has shown his mettle," tr. A. H. Johns, in "A Poet between Two Worlds: The Work of Sitor Situmorang," in

Bangun Indonesia, special issue of Westerly (Oct. 1966), p. 36 (BT).

"Waking," tr. Jean Kennedy \& Burton Raffel, in "Chapbook," p. 21.

"Awake," tr. Jean Kennedy, in Raffel, Forked Tongue, pp. 90-91 (BT).

"Waking," tr. Kennedy \& Raffel, in ibid., pp. 90-91 (BT).

Berita perdjalanan "News of the journey," tr. M. Balfas, in RIMA, 7, 2 (July-Dec. 1973), pp. 69-70 (BT).

Bunga "A flower," tr. Raffel, in Development, p. 129.

Bunga diatas batu "On the stone," tr. Anas Ma'ruf, in Anas Ma'ruf, "Modern Indonesian Literature," a speech delivered 15th September 1957 before the students of Seoul National University (Seoul, 1957), p. 4 (BT).

Cathédrale de Chartres

"Cathédrale de Chartres," tr. Raffel, in Development, pp. 130-31. 
SIT UMORANG, Sitor (continued)

Cathédrale de Chartres (continued)

"Cathedrale de Chartres," tr. Muhammad Haji Salleh, in Tenggara, 5 (1969), pp. 4-7 (BT).

"Cathédrale de Chartres," tr. S. Thornton, in José, Asian PEN, pp . 160-61.

"Chartres Cathedral," tr. ?, in Wigmore, Span, pp. 247-48.

Gambar kota kulu

"City picture," tr. Jean Kennedy, in Raffel, Forked Tongue, pp. 92-93 (BT).

"The city seen as it was," tr. Kennedy \& Raffel, in ibid., pp. 92-93 (BT).

Gunung seribu, Jogja "Thousand mountains, Jogja," tr. Kennedy \& Raffel, in ibid., pp. 96-97 (BT).

Kepada orang mati "To the dead," tr. Muhammad Haji Salleh, in Tenggara, 5 (1969), pp. 8-9 (BT).

Kolam berenang

"Swimming pool," tr. Jean Kennedy \& Burton Raffel, in Poetry Northwest, 4, $3 / 4(1963 / 64)$, pp. 58-61 (BT).

"Swimming pool: for Rulan," tr. Kennedy \& Raffel, in Shimer, Mentor Book, p. 69 .

La ronde: I

"La ronde: I," tr. Jean Kennedy, in Raffel, Development, p. 126.

"La ronde: I," tr. Kennedy, in Raffel, Forked Tongue, pp. 94-95 (BT).

"La ronde: I," tr. Kennedy, revised by Raffel, in ibid., pp. 94-95.

La ronde: II "La ronde: II," tr. Salleh, in Tradition \& Change, p. 29 (BT).

Lagu gadis Itali

"An Italian girl's song," tr. Raffel, in Development, pp. 127-28 (BT).

"Song of an Italian girl," tr. Salleh, in Tradition \& Change, p. 103 (BT).

Lapangan pagi: Sukabumi

"Morning meadow: Sukabumi," tr. Jean Kennedy \& Burton Raffel, in Poetry Northwest, 4, 3/4 (1963/64), pp. 60-61 (BT).

"Morning field," tr. Teeuw (partly based on a translation by Johns \& Raffel), in $M I L, \mathrm{pp} .188,268(\mathrm{BT})$.

Pagi "Morning," tr. Jean Kennedy \& Burton Raffel, in Poetry Northwest, 4, $3 / 4$ $(1963 / 64)$, pp. 62-63 (BT).

Pantun "Pantun," tr. Raffel, in Development, p. 129.

Paris, janvier "Paris, January," tr. Derwent May, in "Indonesia's Revolutionary Culture," Eastern World, 14, 11 (1960), p. 19.

Paskah "Easter," tr. Raffel, in Development, p. 132.

Patrice Lumumba "Patrice Lumumba," tr. Bintang Suradi, in We All Are, pp. 11-12.

Paul Eluard "Paul Eluard," tr. Salleh, in Tradition \& Change, p. 77.

Pelarian "Flight," tr. M. Balfas, in RIMA, 7, 2 (1973), p. 68 (BT).

Place St. Sulpice "Place St. Sulpice," tr. Salleh, in Tradition \& Change, p. 61 (BT).

Sungai bening "Clear river," tr. Jean Kennedy \& Burton Raffel, in Raffel, Development, p. 125. $\frac{\text { Udara pagi di Peking }}{131-32(\mathrm{BT})}$. Morning air in Peking," tr. Raffel, in Development, pp.

Ziarah dalam geredja gunung

"Pilgrimage to a mountain church," tr. Harry Aveling, in "Religion and Blasphemy in Modern Indonesian Literature," in 20th Century, 24, 3 (Autumn 1970), p. 220.

"A visit in a mountain church," tr. A. H. Johns, in "Anthology of Modern Indonesian Poetry," Hemisphere, 10,2 (1966), pp. 9-10 (BT).

"A visit to a mountain church," tr. Johns, in "A Poet between Two Worlds: The Work of Sitor Situmorang," Indonesia, special issue of Westerly (Oct. 1966), p. 31 (BT). 
SITUMORANG, Sitor (continued)

Ziarah dalam geredja gunung (continued)

"Visit to a grave in a mountain church," tr. Burton Raffel, in A. H. Johns, "Anthology of Modern Indonesian Poetry," Hemisphere, 10, 2 (1966), p. 9 (BT).

. "A Cuban maid in Peking," tr. Bintang Suradi, in CPIP, p. 62.

"Asian-African solidarity," tr. Bintang Suradi, in Indonesia Sings, p. 15.

"Eating the bread of the commune," tr. Bintang Suradi, in CPIP, pp. 63-64.

- "(The image)," tr. ?, in PEN-Kwartaal 31. Periodiek van het Nederlands en het Vlaams PEN-centrum (Oct.-Dec. 1977), p. 15.

. "The steel mill," tr. Bintang Suradi, in CPIP, p. 61.

SLAMET Kirnanto

Sajak "Poem," tr. Hilgers-Hesse, in "Some Thoughts," p. 14 (BT).

SOBRON Aidit see AIDIT, Sobron

SOSRODANUKUSUMO, Hadi see HADI Sosrodanukusumo

ST. M.

. "All passeth," tr. Ali, in Flaming Earth, p. 19.

SUBAGIO Sastrowardojo

Abad 20 "Twentieth century," tr. Salleh, in Tradition \& Change, p. 39 (BT).

Adam di Firdaus "Adam in Paradise," tr. Raffel, in Development, p. 157.

Anak menangis "A child cries," tr. Teeuw, in $M / L, p p .236,270-71$ (BT).

Asmaradana "Asmaradana," tr. Surjotjondoro-Leake, in "Kayon," p. 37 (BT).

Bima "Bima," tr. Surjotjondoro-Leake, in "Kayon," pp. 35-36 (BT).

Daerah perbatasan

"The border," tr. Aveling, in Translations, p. 27.

"The border," tr. Aveling, in CIP, pp. 112-13 (BT).

Dalang "Puppeteer," tr. Surjotjondoro-Leake, in "Kayon," pp. 39 (BT).

Diantara gedung pentjakar

"Among sky-scrapers," tr. Aveling, in Translations, p. 30.

"Among sky-scrapers," tr. Aveling, in CIP, pp. 122-23 (BT).

Diudjung randjang

"At the end of the bed," tr. Aveling, in Translations, p. 29.

"At the end of the bed," tr. Aveling, in CIP, pp. 118-19 (BT).

"At the edge of the bed," tr. Salleh, in Tradition \& Change, p. 146 (BT).

Hari Natal

"Christmas day," tr. Aveling, in Translations, p. 24.

"Christmas day," tr. Aveling, in CIP, pp. 102-3 (BT).

Kata

"The word," tr. Aveling, in Translations, p. 29.

"The word," tr. Aveling, in CIP, pp. 120-21 (BT).

Kayal Arjuna "Arjuna's dream," tr. Surjotjondoro-Leake, in "Kayon," pp. 36- 37 (BT).

Kayon "Kayon," tr. Surjotjondoro-Leake, in "Kayon," p. 33 (BT). Lahir sadjak

"The birth of a poem," tr. Harry Aveling, in "Indonesian Poetry Today," Hemisphere, 16, 1 (Jan. 1972), p. 11 .

"The birth of a poem," tr. Aveling, in Translations, p. 23.

"The birth of a poem," tr. Aveling, in CIP, pp. 98-99 (BT).

L'éducation sentimentale

"L'éducation sentimentale," tr. Aveling, in Translations, p. 24.

"L'éducation sentimentale," tr. Harry Aveling, in Tenggara, 6 (1973), pp. $48-49$ (BT).

"L'éducation sentimentale," tr. Aveling, in CIP, pp. 104-5 (BT). 
SUBAGIO Sastrowardojo (continued)

Manusia pertama diangkasa luar

"The first man in outer space," tr. Aveling, in Translations, pp. 25-26.

"The first man in outer space," tr. Aveling, in CIP, pp. 108-11 (BT).

Matinya pandawa yang saleh "Death of a virtuous pandawa," $t r$. SurjotjondoroLeake, in "Kayon," p. 36 (BT).

Nawang Wulan

"Nawang Wulan (the guardian of the earth and of rice)," tr. Aveling, in Translations, p. 25.

"Nawang Wulan," tr. Aveling, in CIP, pp. 106-7 (BT).

New York

"New York," tr. Aveling, in Translations, p. 28.

"New York," tr. Aveling, in CIP, pp. 116-17 (BT).

"New York," tr. Salleh, in Tradition \& Change, pp. 48-49 (BT).

Pagelaran "Performance," tr. Surjotjondoro-Leake, in "Kayon," p. 34 (BT).

Pembitjaraan, No. II "Talk, No. II," tr. Raffel, in Development, pp. 158-59.

Petundjuk sutradara

"The producer's directions," tr. Aveling, in "Impressions," p. 72.

"The producer's directions," tr. Harry Aveling, in "Indonesian Poetry Today," Hemisphere, 16, 1 (Jan. 1972), p. 11.

"The producer's directions," tr. Aveling, in Translations, p. 23.

"The producer's directions," tr. Aveling, in CIP, pp. 100-101 (BT).

Pidato dikubur orang

"Speech at a graveside," tr. Aveling, in Translations, pp. 27-28.

"Speech at a graveside," tr. Aveling, in CIP, pp. 114-15 (BT).

Saldju "Snow," tr. Muhammad Haji Salleh, in Tenggara, 5 (1969), pp. 10-11 (BT).

Saudara kembar "Twin," tr. Surjotjondoro-Leake, in "Kayon," pp. 34-35 (BT).

Sayap patah "Broken wing," tr. Surjotjondoro-Leake, in "Kayon," pp. 38-39 (BT).

Seperti pisau belati "Like a knife," tr. Surjotjondoro-Leake, in "Kayon," p. 38 (BT).

Setasion "Station," tr. Salleh, in Tradition \& Change, p. 62 (BT).

Sodom dan Gomorrha "Sodom and Gomorrha," tr. Salleh, in ibid., p. 63 (BT).

Wayang "Shadow puppet," tr. Surjotjondoro-Leake, in "Kayon," p. 34 (BT).

- "And death becomes more intimate," tr. Fadjri Alimuddin, in Solidarity, 3, 9 (Sept. 1968), pp. 20-21.

. "Monolith," tr. Raffel, in Development, p. 157.

SUDISMAN

- "Radiant Baku," tr. Bintang Suradi, in CPIP, p. 71.

"The struggle of Erevan," tr. Bintang Suradi, in ibid., pp. 72-73.

"The struggle of Erevan," tr. Bintang Suradi, in Indonesia Sings, pp. 16-17.

SUGIARTI Siswadi

- "Freedom," tr. Bintang Suradi, in CPIP, p. 66.

"Women," tr. Bintang Suradi, in ibid., p. 65.

SULANG, Kusni see KUSNI Sulang

SULARKO

Tahun bertahun "Year after year," tr. Raffel, in Development, pp. 231-32.

SOEMARDJO

. "The door," tr. Ali, in Flaming Earth, p. 30.

SUMARDJO, Trisno see TRISNO Sumardjo

SUPANGAT, Louise Walujati see WALUJATI, Louise

SUPRIJADI, Piek Ardijanto see PIEK Ardijanto Suprijadi 


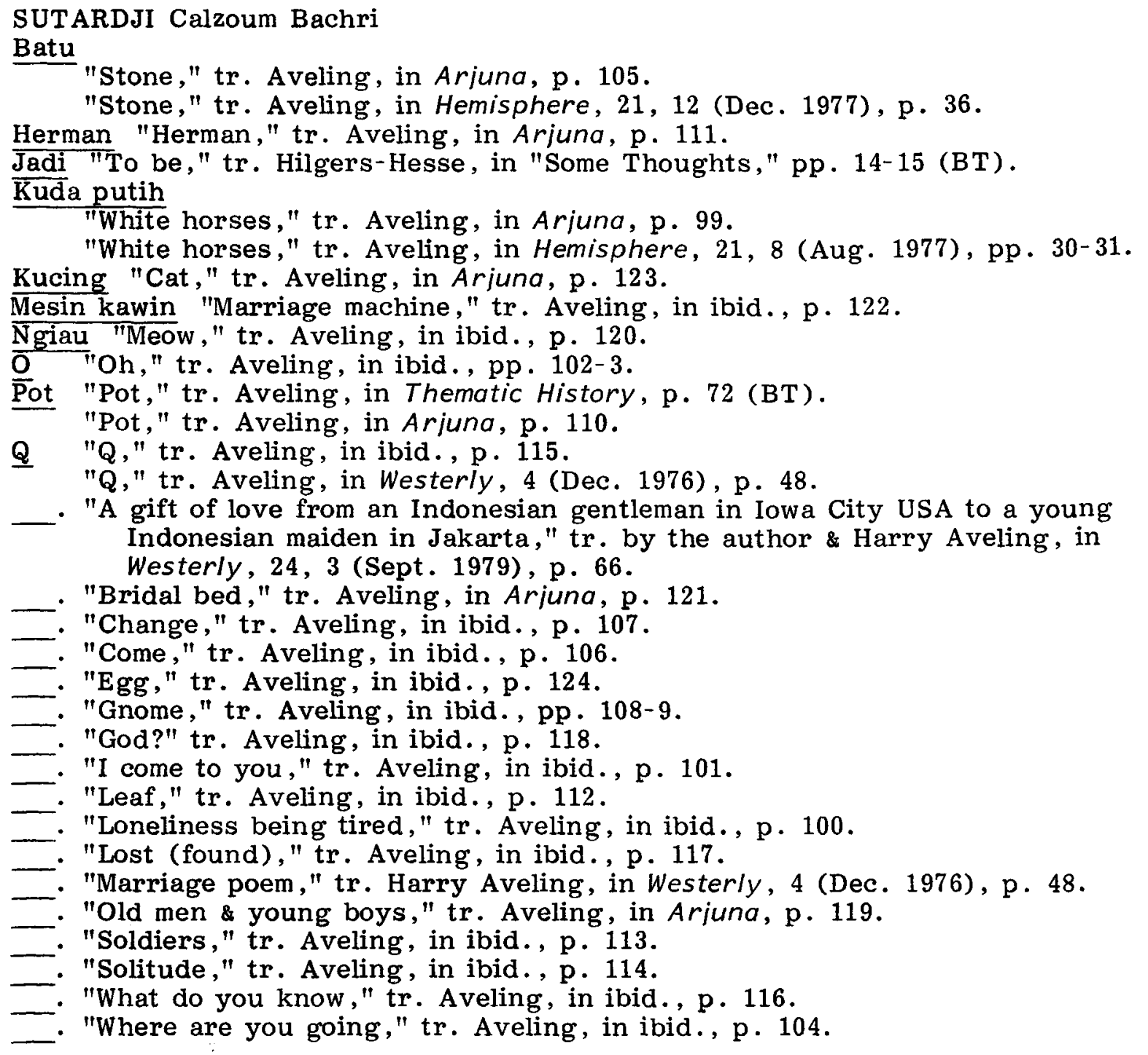

TAKDIR Alisjahbana, Sutan

Bertemu

"Meeting," tr. Burton Raffel \& Nurdin Salam, in Echols, IWT, p. 31.

"Meeting," tr. Raffel \& Salam, in POI, p. 121.

"Meeting," tr. Raffel \& Salam, in Raffel, AMIP, p. 36.

"Meeting," tr. Raffel \& Salam, in Raffel, "Beginnings," p. 75.

"Meeting," tr. Raffel \& Salam, in José, Asian PEN, p. 159.

"Meeting," tr. Raffel \& Salam, in Raffel, Development, pp. 60-61.

Dalam gelombang "In the waves," tr. Raffel, in ibid., pp. 59-60.

Menudju kelaut "Heading for the sea," tr. Teeuw, in MIL, pp. 34-35, 261 (BT). Ni'mat hidup "The pleasures of life," tr. Raffel, in Development, pp. 58-59 (BT). Tjandi Prambanan "Tjandi Prambanan," tr. Teeuw, in MIL, pp. 35, 261 (BT).

- "Oh most beautiful," tr. Raffel \& Salam, in Echols, IWT, p. 31.

"Stillness and peace?" tr. ?, in Modern Literature in Indonesia (New York:

Indonesian Information Office, n.d.), p. 1.

TASRIF

. "In search of a goal," tr. Ali, in Flaming Earth, p. 32.

- "The boatman," tr. Ali, in ibid., p. 31 . 
TATENGKENG, Johannes Engelbert

Dipantai, waktu petang

"On the shore: twilight," tr. Raffel, in Development, p. 65.

"On the shore: twilight," tr. Burton Raffel \& Nurdin Salam, in Shimer, Mentor Book, p. 66.

Penumpang kelas I

"Traveler first class," tr. James S. Holmes, in "Chapbook," p. 23.

"Traveler first class," tr. Holmes, in Raffel, AMJP, p. 48.

"Traveler first class," tr. Holmes, in José, A sian PEN, p. 163.

"Traveler first class," tr. Holmes, in Raffel, Development, pp. 112-13 (BT).

"Traveler first class," tr. Holmes, in Shimer, Mentor Book, pp. 65-66.

Perasaan seni

"My feeling for art," tr. Burton Raffel \& Nurdin Salam, in Raffel, "Beginnings," p. 76.

"My feeling for art," tr. Raffel, in Development, pp. 63-64 (BT).

Willem Kloos "Willem Kloos," tr. Teeuw, in MIL, pp. 44, 261-62 (BT).

TAUFIQ Ismail

Adalah bel ketjil di djendela

"A small bell in the window," tr. Aveling, in "Contemporary," p. 106.

"A small bell in a window," tr. Aveling, in Translations, p. 34.

"A small bell in a window," tr. Aveling, in CIP, pp. 170-71 (BT).

Aku ingin menulis puisi, jang

"I want to write poetry," tr. Aveling, in Translations, pp. 41-44.

"I want to write poetry," tr. Aveling, in CIP, pp. 188-95 (BT).

Arithmetik sederhana "Simple arithmetic," tr. A. H. Johns, in "Through Myth and Dream: The Indonesian Quest for Reality," Quadrant, 61, 13, 5 (Sept.Oct. 1969), p. 31.

Bagaimana kalau

"What if,"tr. Aveling, in Translation, p. 38.

"What if," tr. Aveling, in CIP, pp. 180-81 (BT).

Beberapa orang dan satu lanskap

"Some people and a landscape," tr. Aveling, in Translations, p. 39.

"Some people and a landscape," tr. Aveling, in CIP, pp. 182-83 (BT).

Bendera "Flag," tr. Adrienne Balfas, in Tenggara, 1 (1967), pp. 108-9 (BT). Bukit biru, bukit kelu

"The silent hills," tr. Aveling, in Translations, p. 33.

"The silent hills," tr. Aveling, in CIP, pp. 166-67 (BT).

"The silent hills," tr. Aveling, in Hemisphere, 20, 7 (July 1976), p. 11.

Dari tjatatan seorang demonstran "Note from a demonstrator," tr. A. H. Johns, in Quadrant, 61, 13,5 (Sept.-Oct. 1969), p. 36.

Doa si kecil "A child's prayer," tr. Muhammad Haji Salleh, in Tenggara, 7 (1975), pp. 10-11 (BT).

Formulir ini

"Formula," tr. Harry Aveling (?), in Solidarity, 6, 9 (Sept. 1971), p. 39.

"Formula," tr. Aveling, in Translations, pp. 36-37.

"Formula," tr. Aveling, in CIP, pp. 176-77 (BT).

Geometri "Geometry," tr. A. H. Johns, in Quadrant, 61, 13, 5 (Sept.-Oct. 1969), p. 36 .

Harmoni "Harmoni," tr. Adrienne Balfas, in Tenggara, 1 (1967), pp. 110-11 (BT).

Horison "Horizon," tr. Keith Foulcher, in "Some Considerations on the Approach to Modern Indonesian Literature," RIMA, 2 (April-June 1968), p. 34 (BT).

Karangan bunga

"Wreath," tr. Adrienne Balfas, in Tenggara, 1 (1967), pp. 110-11 (BT).

"A wreath," tr. A. H. Johns, in Quadrant, 61, 13, 5 (Sept.-Oct. 1969), p. 35. 
TAUFIQ Ismail (continued)

Kita adalah pemilik sjah republik ini

"The republic is ours," tr. Aveling, in Translations, pp. 33-34.

"The republik is ours," tr. Aveling, in CIP, pp. 168-69 (BT).

"This is our nation," tr. A. H. Johns, in Quadrant, 61, 13, 5 (Sept.-Oct. 1969), p. 35.

Menunggu itu

"Waiting is," tr. Harry Aveling, in "Indonesian Poetry Today," Hemisphere, 16, 1 (Jan. 1972), p. 10.

"Waiting is," tr. Aveling, in Translations, p. 35.

"Waiting is," tr. Aveling, in CIP, pp. 172-75 (BT).

Merdeka Utara "Merdeka Utara," tr. Adrienne Balfas, in Tenggara, 1 (1967), pp. $110-11$ (BT).

Refleksi seorang pedjuang tua "Reflections of an old fighter," tr. Harry Aveling, in Southeast Asia: Documents of Political Development and Change, ed. Roger M. Smith (Ithaca: Cornell University Press, 1974), pp. 209-10.

Silhuet (1) "Shadow (1)," tr. Adrienne Balfas, in Tenggara, 1 (1967), pp. 106-7 (BT).

Silhuet (2) "Shadow (2)," tr. Adrienne Balfas, in ibid., pp. 106-7 (BT).

Silhuet (3) "Shadow (3)," tr. Adrienne Balfas, in ibid., pp. 106-7 (BT).

Silhuet (4) "Shadow (4)," tr. Adrienne Balfas, in ibid., pp. 108-9 (BT).

Suara

"The voice," tr. Harry Aveling (?), in Solidarity, 6, 9 (Sept. 1971), p. 39.

"The voice," tr. Aveling, in Translations, p. 37.

"The voice," tr. Aveling, in CIP, pp. 178-79 (BT).

Tableau mendjelang malam "Tableau at dusk," tr. A. H. Johns, in Quadrant, 61, 13,5 (Sept.-Oct. 1969), p. 36.

This form "This form," tr. by the poet (?), in Solidarity, 3, 9 (Sept. 1968), p. 2. $06: 30$

"6:30 a.m.," tr. Aveling, in "Poetry and the Indonesian Revolution," p. 45.

"06.30," tr. Adrienne Balfas, in Tenggara, 1 (1967), pp. 104-7 (BT).

- "Give Indonesia back to me," tr. Aveling, in Translations, pp. 40-41.

"Give Indonesia back to me," tr. by the author, in Writing from the World, ed. Paul Engle \& Hualing Nieh Engle (Iowa City: University of Iowa International Writing Program, 1976), p. 51.

TIAS

- "A voice from abroad," tr. M. A. Jaspan, in Indonesia, special issue of Westerly (Oct. 1966), p. 24.

TJUNG, Benni

- "Partnership," tr. Bintang Suradi, in CPIP, p. 76.

"Partnership," tr. Bintang Suradi, in Indonesia Sings, p. 8.

. "The ballad of Upit," tr. Bintang Suradi, in CPIP, p. 77.

TOTO Sudarto Bachtiar

Djari "His fingers," tr. Burton Raffel \& Nurdin Salam, in Raffel, Development, p. 135.

Gadis peminta-minta "The beggar girl," tr. Teeuw, in $M I L$, pp. 211, 269 (BT) .

Ibukota sendja

"Djakarta in the evening," tr. Derwent May, in Raffel, Development, pp. 136-37.

"Djakarta in the evening," tr. May, in Shimer, Mentor Book, p. 71.

Kepada orang mati "To a dead man," tr. Derwent May, in Raffel, Development, pp. 133-34 (BT).

Muka "My face," tr. Burton Raffel \& Nurdin Salam, in ibid., p. 135. 
TOTO Sudarto Bachtiar (continued)

Nokturno

"Nocturno," tr. Burton Raffel \& Nurdin Salam, in Poetry Northwest, 4, 3/4 (1963/64), pp. 58-59 (BT).

"Nocturno," tr. Raffel \& Salam, in Raffel, Development, pp. 135-36.

Siuman "Conscious" [translation originally untitled], tr. Salleh, in Tradition \& Change, p. 105 (BT).

Tentang kemerdekaan "On the subject of freedom," tr. Burton Raffel \& Nurdin Salam, in Raffel, Development, p. 136.

TRISNO Sumardjo

Sedjarah "History," tr. Muhammad Haji Salleh, in Tenggara, 8 (1976), pp. 12-15 (BT).

Seorang tua dirandjang sakit "For an old man sick in bed," tr. Mary Hodgkin, in Indonesia, special issue of Westerly (Oct. 1966), p. 27.

Usia "Age," tr. Muhammad Haji Salleh, in Tenggara, 8 (1976), pp. 14-15 (BT).

- "Don't build a wall," tr. Aveling (?), in Solidarity, 7, 1 (Jan. 1972), p. 2.

- "The dying bird," tr. Aveling (?), in ibid., p. 2.

TOETI Heraty

Cyclus

"Cyclus," tr. Aveling, in Translations, pp. 66-71. ["Postponement," pp. 66-67; "Repetition," pp. 67-68; "Cocktail party," pp. 68-69; "Cyclus," pp. 70-71.]

"Cyclus," tr. Aveling, in CIP, pp. 148-63. [A tetralogy of poems consisting of "Penundaan (Postponement)," pp. 148-51; "Sekali-sekali (Repetition)," pp. 152-55; "Cocktail party (Cocktail party)," pp. 156-59; and "Cyclus (Cyclus)," pp. 160-63.] (BT).

Kini baru kumengerti

"Now I understand," tr. Aveling, in Translations, pp. 61-62.

"Now I understand," tr. Aveling, in CIP, pp. 138-39 (BT).

Nelajan tunggal

"Lone fisherman," tr. Aveling, in Translations, pp. 63-64.

"Lone fisherman," tr. Aveling, in CIP, pp. 142-43 (BT).

"Lone fisherman," tr. Aveling, in Hemisphere, 20, 12 (Dec. 1976), p. 16.

Panta rei

"Panta rei," tr. Aveling, in Translations, p. 57.

"Panta rei," tr. Aveling, in CIP, pp. 126-27 (BT).

"Panta rei," tr. Salleh, in Tradition \& Change, pp. 164-65 (BT).

Penundaan "Postponement," tr. Harry Aveling, in Tenggara, 6 (1973), pp. 46-47 (BT).

Pesta Tahun Baru

"New Year's celebrations," tr. Aveling, in "Contemporary," p. 107.

"New Year's celebrations," tr. Aveling, in CIP, pp. 130-31 (BT).

Pretensi

"Pretension," tr. Aveling, in Translations, p. 59.

"Pretension," tr. Aveling, in CIP, pp. 132-33 (BT).

Pria "Man," tr. Aveling, in Translations, pp. 57-58.

"Man," tr. Aveling, in CIP, pp. 128-29 (BT).

"Man," tr. Aveling, in Hemisphere, 20, 12 (Dec. 1976), pp. 15-16.

Saat-saat gelap

"Dark moments," tr. Aveling, in "Contemporary," p. 109.

"Dark moments of meeting," tr. Aveling, in Translations, p. 60.

"Dark moments of meeting," tr. Aveling, in Tenggara, 6 (1973), pp. 42-43 (BT).

"Dark moments of meeting," tr. Aveling, in CIP, pp. 134-35 (BT). 
TOETI Heraty (continued)

Sekali-sekali "Repetition," tr. Harry Aveling, in Tenggara, 6 (1973), pp. 44-45

Selesai $(\overline{\mathrm{BT}})$.

"Finished," tr. Aveling, in Translations, pp. 62-63.

"Finished," tr. Aveling, in CIP, pp. 140-41 (BT).

Suatu departemen

"Government department," tr. Aveling, in Translations, pp. 64-65.

"Government department," tr. Aveling, in CIP, pp. 144-47 (BT).

Tjintaku tiga

"I have three loves," tr. Aveling, in "Contemporary," pp. 107-8.

"I have three loves," tr. Harry Aveling in collaboration with the poet, in Aveling, "Indonesian Poetry Today," Hemisphere, 16, 1 (Jan. 1972), pp. $10-11$.

"I have three loves," tr. Aveling, in Translations, pp. 60-61.

"I have three loves," tr. Aveling, in CIP, pp. 136-37 (BT).

USMAR Ismail

Kebangunan "Awakening," tr. M. A. Jaspan, in Indonesia, special issue of Westerly (Oct. 1966), p. 20.

Kudengar azan "I hear the call of the prayer," tr. Sularko (?), in Usman, "Introduction," p. 33 .

WALUJATI, Louise

Berpisah

"Parting," tr. Burton Raffel \& Nurdin Salam, in POI, p. 144.

"Parting," tr. Raffel \& Salam, in Echols, IWT, p. 66.

"Parting," tr. Raffel \& Salam, in Raffel, AMIP, p. 96.

"Parting," tr. Raffel \& Salam, in Raffel, Development, p. 114.

WING Kardjo

Le poète maudit "Le poète maudit," tr. Muhammad Haji Salleh, in Tenggara, 7 (1975), pp. 12-13 (BT).

WISPI, Agam see AGAM Wispi

$\mathrm{Y}$

- "The key to life," tr. Ali, in Flaming Earth, p. 34.

YAMIN, Mohammad

Bahasa, bangsa "Language, nation," tr. Teeuw, in MIL, pp. 10, 257 (BT).

Cinta "Love," tr. Foulcher, in "PMSP," pp. 39-40 (BT).

Gembala

"A shepherd," tr. Raffel, in "Beginnings," p. 71.

"A shepherd," tr. Raffel, in Development, pp. 32-33 (BT).

Gubahan "A wreath," tr. Raffel, in ibid., p. 36.

YUDHO, S.

Bahasaku "My language," tr. Teeuw, in $M I L, p p .30,260$ (BT).

YOESMANAN, M.

Penjerbuan "Invasion," tr. Raffel, in Development, p. 153. 


\section{SHORT STORIES}

ACHDIAT Karta Mihardja

Hamid

"Hamid," tr. Robert MacQuaid, in POI, pp. 159-63.

"Hamid," tr. MacQuaid, in Echols, IWT, pp. 129-41.

"Hamid," tr. MacQuaid, in Wigmore, Span, pp. 236-46.

"Hamid," tr. MacQuaid, in 50 Great Oriental Stories, ed. Gene Z. Hanrahan (New York: Bantam Books, 1965), pp. 352-61.

Sensasi dipuntjak njiur

"Sensation at the top of a coconut tree," tr. Benedict Anderson, in A Treasury of Modern Asian Stories, ed. Daniel L. Milton \& William Clifford (New York: The New American Library, 1961), pp. 143-56.

"Sensation at top of coconut palm!" tr. A. H. Johns, in Meanjin, 83, 19, 4 (1960), pp. 389-99.

"Sensation in the crown of the coconut tree," tr. M. Opit and L. Kroutilová, in New Orient, 4 (June 1965), pp. 89-93.

- "Van Buren and the village girl," tr. ?, in José, Asian PEN, pp. 173-78.

"Van Buren and the village girl," tr. ?, in Of Love and Hope: Fourteen Stories from Africa and Asia (Lahore: The Afro-Asian Book Club, 1966), pp. 141-47.

AJIP Rosidi

Ditengah keluarga "Among the family," tr. S. U. Nababan, in Indonesia, 1 (April 1966), pp. 117-23.

. "A Japanese," tr. William Frederick, in Indonesia, 6 (Oct. 1968), pp. 82-87.

ALEIDA, Martin

. "Dark night," tr. Aveling, in Gestapu, pp. 83-96.

AMAL Hamzah

Teropong "Spy-glass," tr. Malcom Willison, in Echols, IWT, pp. 87-89.

AMRULLAH, Hadji Abdul Malik Karim see HAMKA

ASRUL Sani

Sahabat saja Cordiaz "My friend Cordiaz Darla," tr. George I. Begley, in Eastern World (London), 4, 1 (Jan. 1950), pp. 34-36.

BALFAS, M.

Anak revolusi "A child of the revolution," tr. Alan M. Stevens, in Indonesia, 17 (April 1974), pp. 43-50.

Ketukan di pintu "The knock on the door," tr. Adrienne Balfas, in Tenggara, 2, 2 (1968), pp. 68-79 (BT).

DANARTO

Abracadabra "Abracadabra," tr. Harry Aveling, in Denver Quarterly, 12, 1 (Spring 1977), pp. 131-42.

Armageddon "Armageddon," tr. Aveling, in Surabaya-Armageddon, pp. 198- 211.

Asmaradana "Asmaradana," tr. Harry Aveling, in Denver Quarterly, 12, 2 (Summer 1977), pp. 5-18.

Labyrinth "Labyrinth," tr. Harry Aveling, in ibid., pp. 29-37.

Nostalgia "Nostalgia," tr. Aveling, in Surabaya-Armageddon, pp. 181-97.

Sandiwara atas sandiwara "A play within a play," tr. Harry Aveling, in Denver Quarterly, 12, 2 (Summer 1977), pp. 18-28.

. "Adam the wisdom of God," tr. Harry Aveling, in Westerly, 4 (Dec. 1976), pp. 51-57. 
DARWIN Effendie, T. B.

Alfatihah "Alfatihah," tr. M. A. Jaspan, in Indonesia, special issue of Westerly (Oct. 1966), pp. 92-93.

DINI, Nh.

Jatayu "Jatayu," tr. Jean Taylor, in Indonesia, 20 (Oct. 1975), pp. 155-60.

DJOJOPUSPITO, Suwarsih see SUWARSIH Djojopuspito

EFFENDIE, T. B. Darwin see DARWIN Effendie, T. B.

GERSON Poyk

Oleng-kemoleng

"The swinging mirror," tr. Musafir Hidayat, in Solidarity, 3, 9 (Sept. 1968), pp. 64-66.

"The swinging mirror," tr. Musafir Hidayat, in Quadrant, 61, 13, 5 (Sept.Oct. 1969), pp. 49-51.

Perempuan dan anak-anaknya "A woman and her children," tr. Aveling, in Gestapu, pp. 58-76.

HAMKA [H. Abdul Malik Karim Amrullah]

Anak tinggal "A deserted child," tr. Hendon, in Six Indonesian Short Stories, pp. 1-18.

HAMZAH, Amal see AMAL Hamzah

HOERIP, Satyagraha see SATYAGRAHA Hoerip

IDRUS

Aki "Aki's song," tr. Echols, in IWT, pp. 91-117.

Fujinkai "Fujinkai," tr. S. U. Nababan, in Indonesia, 2 (Oct. 1966), pp. 125-29.

Kissah sebuah tjelana pendek "The shorts," tr. George I. Begley, in Eastern World, 5, 12 (Dec. 1951), pp. 30-31.

Och...och...och!

"Och..och...och," tr. S. U. Nababan, in Indonesia, 2 (Oct. 1966), pp. 129-34.

"Oh...oh...oh...! A story," tr. ?, in POI, pp. 31-32.

Soerabaja

"Surabaja," tr. S. U. Nababan \& Benedict Anderson, in Indonesia, 5 (April 1968), pp. 1-28.

"Surabaya," tr. Aveling, in Surabaya-Armageddon, pp. 1-28.

JOKE Muljono see Muljono, Joke

KAYAM, Umar see UMAR Kayam

KIPANDJIKUSMIN

Langit makin mendung "The darkening sky," tr. Marian de Walt Morgan (Honolulu: University of Hawaii Southeast Asian Studies Program, 1974).

- "Cain's lamb," tr. Aveling, in Gestapu, pp. 1-11.

- "Star of death," tr. Aveling, in ibid., pp. 27-35.

LUBIS, Mochtar

Lotre Hadji Zakaria

"The lotteries of Haji Zakaria," tr. Robert MacQuaid, in POI, pp. 142-44.

"The lotteries of Haji Zakaria," tr. MacQuaid, in Wigmore, Span, pp. 51-56.

"The lotteries of Haji Zakaria," tr. MacQuaid, in 50 Creat Oriental Stories, ed. Gene Z. Hanrahan (New York: Bantam Books, 1965), pp. 361-67.

Si Djamal berinfiltrasi "Djamil infiltrating," tr. Dean J. Almy, Jr., in Echols, IWT, pp. 124-27.

Si Djamal gerilja kota "Djamil, city guerrilla," tr. Judith Rosenberg, in Echols, IWT, pp. 119-23. 
LUBIS, Mochtar (continued)

- "Contract coolies," tr. A. H. Johns, in Hemisphere, 10, 12 (Dec. 1966), pp. 23-25.

MOELJONO, Joke

- "The crickets," tr. James S. Holmes, in Pacific Spectator, 7, 1 (Winter 1953), pp. 48-50.

NAVIS, A. A.

Robohnja surau kami

"The decline and fall of our local mosque," tr. Aveling, in Surabaya-Armageddon, pp. 117-26.

"The decline and fall of our local mosque," tr. Aveling, in Short Story International, 4, 19 (April 1980), pp. 85-92.

NUGROHO, Sosiawan see SOSIAWAN Nugroho

NUGROHO Notosusanto

Kepindahan "The transfer," tr. Aveling, in Surabaya-Armageddon, pp. 112-16. Panser

"The soldier," tr. Aveling, in ibid., pp. 102-11.

"The soldier," tr. Aveling, in Short Story International, 4, 20 (June 1980), pp. 63-71.

PANÉ, Armijn

Imperialis terpagar "Imperialists fenced in," tr. Dean J. Almy, Jr., in Echols, IWT, pp. 53-55.

Kandang ajam "The chicken coop," tr. A. Brotherton, in POI, pp. 122-23.

Sakit gigi "Toothache," tr. Hendon, in Six Indonesian Short Stories, pp. 60-96.

POYK, Gerson see GERSON Poyk

PRAMOEDYA Ananta Toer

Anak haram "The bastard," tr. Aveling, in Surabaya-Armageddon, pp. 41-68. Bukan pasar malam

"No night market," tr. Aveling, in Pramoedya, Heap of Ashes, pp. 107-59.

"It's not an all night fair," translated \& with an introduction by William Watson, in Indonesia, 15 (April 1973), pp. 21-80.

Dendam "Revenge," tr. Benedict Anderson, in Indonesia, 26 (Oct. 1978), pp. 43-61. Dia jang menjerah

"The vanquished," tr. Aveling, in Pramoedya, Heap of Ashes, pp. 45-105.

"The vanquished," tr. William Frederick \& John McGlynn in forthcoming Ohio University Southeast Asia series publication (1981).

Djakarta

"Letter to a friend from the country," tr. Harry Aveling, in Quadrant, 61, 13, 5 (Sept.-Oct. 1969), pp. 59-64.

"Letter to a friend from the country," tr. Aveling, in Surabaya-Armageddon, pp. 69-76.

Hadiah kawin "The reward of marriage," tr. Ann Kumar, in Indonesia, special issue of Westerly (Oct. 1966), pp. 43-68.

Inem

"Inem," tr. Harry Aveling, in Luna: A Literary Publication [Kew, Victoria], 2,2 (1967), pp. 24-29.

"Inem," tr. Aveling, in Surabaya-Armageddon, pp. 29-40.

"Inem," tr. Hendon, in Six Indonesian Short Stories, pp. 41-59.

"Inem," tr. A. H. Johns, in Meaniin, 95, 22, 4 (Dec. 1963), pp. 365-74.

Jang hitam "Darkness," tr. ?, in Indonesia, special issue of Westerly (Oct. 1966), pp. 76-91. 
PRAMOEDYA Ananto Toer (continued)

Jang sudah hilang

"Lonely paradise," tr. Aveling, in Pramoedya, Heap of Ashes, pp. 1-24.

"Lonely paradise," tr. Aveling, in Tabloid Story [GPO Box 4430, Sydney, NSW 2001] (n.d.), pp. 8-11.

"Vanished childhood," tr. Harry J. Benda, in Echols, IWT, pp. 153-71.

"Things vanished," tr. with a commentary by James T. Siegel, in Glyph, 1 (1977), pp. 67-100.

Kemudian lahirlah dia

"The birth," tr. Aveling, in Pramoedya, Heap of Ashes, pp. 25-43.

"Born before the dawn," tr. A. Brotherton, in POI, pp. 114-16.

"Born before the dawn," tr. ?, in Wigmore, Span, pp. 118-24.

Sunat "Circumcision," tr. Harry Aveling, in Westerly, 24, 3 (Sept. 1979), pp. 69-72.

Sunjisenjap disiang hidup "The silent centre of life's day," tr. Aveling, in Pramoedya, Heap of Ashes, pp. 161-77.

. "Caged," tr. Goh Liantji, in Indonesia, special issue of Westerly (Oct. 1966), pp. 69-75.

PRIJANA Winduwinata

Djangan mendjadi guru "Don't become a teacher," tr. Benedict Anderson, in Indonesia, 25 (April 1978), pp. 110-14.

M.M.M. "Mission for macroeconomic maximization," tr. Benedict Anderson, in ibid. , pp. 84-90.

M.M.M. dan lain ${ }^{2}$ tjeritera binatang modern "M.M.M.: five animal tales," tr. Benedict Anderson, in ibid., pp. 81-114.

Pemilihan anggota D.D.T. "Elections to the supreme village council," tr. Benedict Anderson, in ibid., pp. 99-104.

Pertandingan ketjantikan "The beauty contest," tr. Benedict Anderson, in ibid., pp. 105-9.

Sekali miljuner, tetap miljuner "Once a millionaire, always a millionaire," $\mathrm{tr}$. Benedict Anderson, in ibid., pp. 91-98.

PRIJONO Winduwinoto see PRIJANA Winduwinata

RENDRA, W. S.

. "Herdjan's way," tr. A. H. Johns, in Hemisphere, 8, 12 (Dec. 1964), pp. 28- 30.

ROSIHAN Anwar

Radio masjarakat "The voice of the people," tr. Karl Strange, in Echols, IWT, pp. 68-85.

ROEKIAH, S.

Kejatuhan dan hati "A surrender of the heart," tr. William Frederick \& John McGlynn in forthcoming Ohio University Southeast Asia series publication (1981).

RUSMAN Sutiasumarga

Meminggir kota "On the outskirts of the city," tr. Hendon, in Six Indonesian Short Stories, pp. 30-40.

SANI, Asrul see ASRUL Sani

SATYAGRAHA Hoerip

. "The climax," tr. Aveling, in Gestapu, pp. 36-50.

SIAHAAN, J. E.

Djika hudjan turun "When the rain came," tr. Toenggoel Siagian, in Indonesia, 27 (April 1979), pp. 93-102. 
SIREGAR, Bakri

Dibalik bukit "Behind the hills," tr. Hendon, in Six Indonesian Short Stories, pp. 97-123.

SIREGAR, Barus

Pemain gambus "The lute player," tr. Hendon, in ibid., pp. 19-29.

SITUMORANG, Sitor

Djin "The djinn," tr. Echols, in IWT, pp. 173-77.

Fontenay aux Roses "Fontenay aux Roses," tr. Aveling, in Surabaya-Armageddon, pp. 85-93.

Ibu pergi kesorga

"Mother goes to heaven," tr. Harry Aveling, in Solidarity, 7, 1 (Jan. 1972), pp. 17-21.

"Mother goes to heaven," tr. Aveling, in Surabaya-Armageddon, pp. 94-101.

"Mother's pilgrimage to Paradise," tr. Oentoeng Soebroto, in Wigmore, Span, pp. 156-63.

Saldju di Paris

"Snow in Paris," tr. Aveling, in Surabaya-Armageddon, pp. 77-84.

"Snow in Paris," tr. Rufus S. Hendon, in Ventures: Magazine of the Yale Graduate School, 9, 1 (1969), pp. 48-54.

SJOEKOER, Mohammad

. "Death," tr. Aveling, in Gestapu, pp. 23-26.

SOSIAWAN Nugroho

. "A minor conflict," tr. Aveling, in ibid., pp. 97-107.

SOEBROTO, Oentoeng see OENTOENG Soebroto

SUTIASUMARGA, Rusman see RUSMAN Sutiasumarga

SUWARSIH Djojopuspito

Riwajat pohon flamboyant "The tale of the flamboyant tree," tr. Muriel B. Lechter, in Echols, IWT, pp. 57-61.

TRISNOYUWONO

. "In the dining-car," tr. E. Vaníčková \& L. Kroutilová, in New Orient, 6 (April 1967), pp. 58-59.

TOER, Pramoedya Ananta see PRAMOEDYA Ananta Toer

UGATI, H. G.

. "The threat," tr. Aveling, in Gestapu, pp. 51-57.

UMAR Kayam

Bawuk

"Bawuk," tr. Aveling, in Surabaya-Armageddon, pp. 135-62.

"Bawuk," tr. William Frederick \& John McGlynn in forthcoming Ohio University Southeast Asia series publication (1981).

Chief Sitting Bull "Chief Sitting Bull," tr. Harry Aveling, in Denver Quarterly, 11, 4 (Winter 1977), pp. 124-28.

Isteriku, Madame Schlitz, dan sang raksasa "My wife, Madame Schlitz, and the giant," tr. Lenie Lumenta, in Solidarity, 3, 9 (Sept. 1968), pp. 67-73.

Seribu kunang-kunang di Manhattan

"A thousand fireflies in Manhattan," tr. Harry G. Aveling, in Solidarity, 5, 9 (Sept. 1970), pp. 47-50.

"A thousand fireflies in Manhattan," tr. Aveling, in Surabaya-Armageddon, pp. 127-34. 
UMAR Kayam (continued)

Sri Sumarah "Sri Sumarah," tr. William Frederick \& John McGlynn in forthcoming Ohio University Southeast Asia series publication (1981).

. "Fall in Connecticut," tr. Aveling, in Surabaya-Armageddon, pp. 163-80.

OENTOENG Soebroto

. "The wish," tr. ?, in Wigmore, Span, pp. 332-36.

USAMAH

. "War and humanity," tr. Aveling, in Gestapu, pp. 12-22.

"War and humanity: notes on personal experience," tr. Helen Jarvis, in Indonesia, 9 (April 1970), pp. 89-100.

UTUY Tatang Sontani

- "Samad's business," tr. Harry Aveling (?), in Lachesis (April 1968), pp. 3-6.

ZULIDAHLAN

. "The valley of the shadow of death," tr. Aveling, in Gestapu, pp . 77-82.

\section{NOVELS}

ACHDIAT K. Mihardja

Atheis Atheis, tr. R. J. Maguire (St. Lucia, Queensland: University of Queensland Press, 1972).

LUBIS, Mochtar

Djalan tak ada udjung $A$ road with no end, tr. \& ed. by Anthony H. Johns (London: Hutchison, [c. 1968]).

Sendja di Djakarta Twilight in Djakarta, tr. Claire Holt (New York: Vanguard Press, 1964).

PRAMOEDYA Ananta Toer

Perburuan The fugitive, tr. Harry Aveling (Hong Kong: Heinemann Educational Books [Asia], 1975).

SIMATUPANG, Iwan

Kering Drought, tr. Harry Aveling (Singapore: Heinemann Educational Books [Asia], 1978).

Ziarah The pilgrim, tr. Harry Aveling (Hong Kong: Heinemann Educational Books, 1975).

DRAMA

ARIFIN C. Noer

Kapai-kapai Moths, tr. Harry Aveling (Kuala Lumpur: Dewan Bahasa dan Pustaka, 1974).

RENDRA, W. S.

Kisah perjuangan suku naga Struggle of the Naga tribe, tr. Max Lane, Asian and Pacific Writing, 11 (St. Lucia: University of Queensland Press, 1979).

Mastodon dan burung kondor The mastodon and the condors, tr. Harry Aveling, Asian and Pacific Writing series (St. Lucia: University of Queensland

Press, forthcoming [1982]). 
UTUY Tatang Sontani

Awal dan Mira "Awal and Mira," tr. Harry Aveling, in Man and Society in the Works of the Indonesian Playwright Utuy Tatang Sontani and Awal and Mira, Southeast Asia Paper no. 13 (Honolulu: Southeast Asian Studies Program, University of Hawaii, 1979), pp. 59-83.

Bunga rumah makan "The flower of the restaurant," tr. John M. Echols \& Patricia M. Pilling in Indonesia, 30 (Oct. 1980), pp. 17-41.

Si Kabajan "Si Kabayan," tr. Adibah Amin, in Three Southeast Asian Plays (Kuala Lumpur: Tenggara, 1970), pp. 1-24. 